\title{
Fate of forest tree biotechnology facing climate change
}

\author{
M. R. Ahuja
}

60 Shivertown Road, New Paltz, NY 12561. USA, E-Mail: mrahuja@hotmail.com

\begin{abstract}
Woody plants have been cultured in vitro since the 1930s. After that time much progress has been made in the culture of tissues, organs, cells, and protoplasts in tree species. Tree biotechnology has been making strides in clonal propagation by organogenesis and somatic embryogenesis. These regeneration studies have paved the way for gene transfer in forest trees. Transgenics from a number of forest tree species carrying a variety of recombinant genes that code for herbicide tolerance, pest resistance, lignin modification, increased woody biomass, and flowering control have been produced by Agrobacterium-mediated and biolistic methods, and some of them are undergoing confined field trials. Although relatively stable transgenic clones have been produced by genetic transformation in trees using organogenesis or somatic embryogenesis, there were also unintended unstable genetic events. In order to overcome the problems of randomness of transgene integration and instability reported in Agrobacterium-mediated or biolistically transformed plants, site-specific transgene insertion strategies involving clustered regularly interspaced short palindromic repeats (CRISPR-Cas9) platform offer prospects for precise genome editing in plants. Nevertheless, it is important to monitor phenotypic and genetic stability of clonal material, not just under greenhouse conditions, but also under natural field conditions. Genetically modified poplars have been commercialized in China, and eucalypts and loblolly pine are expected to be released for commercial deployment in USA. Clonal forestry and transgenic forestry have to cope with rapid global climate changes in the future. Climate change is impacting species distributions and is a significant threat to biodiversity. Therefore, it is important to deploy Strategies that will assist the survival and evolution of forest tree species facing rapid climate change. Assisted migration (managed relocation) and biotechnological approaches offer prospects for adaptation of forest trees to climate change.
\end{abstract}

Keywords: Biotechnology, Clonal propagation, Genetic engineering, Transgenic trees, Genetic stability, Transgene containment, Climate change, Climate mitigation and Adaptation

\section{Introduction}

Theoretical basis for cell culture and concept of totipotency in plant cells were first formulated by Gottlieb Haberlandt in 1902. It was almost three decades later when Roger Gautheret in 1934 was the first to culture pieces of cambium cut from trees (Salix capraea, and Acer pseudoplatinus, and Sambucus nigra) in culture media. Initially, he did not expect much success, but two months later when he examined his culture, he noticed callus growth on them. Unfortunately, Gautheret's cultures ceased to grow after 6 months, because of some deficiency in the culture medium. Six years later, Gautheret (1940) was able to obtain bud formation from cambial tissues of Ulmus campestris L. and Populus nigra L. A decade later, Ball (1950) was able to induce buds on callus cultures of Sequoia semperviren. Winton (1968) was the first to achieve plantlet formation from callus cultures of triploid quaking aspen. That was the beginning of clonal plant production in angiosperm forest trees by tissue culture technology. In a sense, it was the beginning of vegetative propagation by micropropagation in forest trees. Vegetative clonal propagation by organogenesis, that is, development of organs from plant tissues in vitro, has been successfully exploited in a number of angiosperm forest tree species (Bonga and Durzan, 1987; Ahuja, 1988a, 1991, 1993a, Ahuja and Libby, 1993a, 1993b; Ahuja et al., 1996; Pardos et al., 1994; Ramawat et al. 2014). And field trials have been conducted in a number of forest tree species to ascertain the phenotypic and genetic fidelity of clonal trees.

Although clonal propagation by organogenesis has often been difficult in conifers because of recalcitrance and maturation state of the trees (Bonga et al., 2010; Bonga, 2012), there 
have been a number of reports on the plantlet regeneration by organogenesis in conifers. The first successful attempt to clonally propagate a conifer by organogenesis was in Pinus palustris by Sommer et al., (1975). Subsequently clonal propagation by organogenesis was achieved in Pseudotsuga menziesii (Gupta and Durzan, 1987), Pinus spp. (Diego et al., 2008, 2010; Cortizo et al., 2009; Bello-Bello et al., 2012; de Oliveira et al 2012), Larix deciduas (Ewald 2007), and Sequoia sempervirens (Boulay, 1978; Arnaud et al., 1993; Ahuja, 1996, 2017; Korban and Sul, 2007). However, somatic embryogenesis has been more successfully exploited for the clonal propagation of a large number of conifer tree species using embryonal tissues and other explants. The first successful reports on somatic embryogenesis appeared in 1985, using immature embryos in Picea abies (Hakman et al., 1985; Chalupa, 1985), and Larix deciduas (Nagmani and Bonga, 1985). After these reports, there has been an explosion of somatic embryogenesis in a large number of conifers, and angiosperm trees (Jain and Gupta 2005; Park et al. 2010; Park and Bonga, 2012, 2014; Park et al., 2016; Bonga, 2016; Guan et al., 2016; Trontin et al., 2016; Tikkinin et al., 2018; Bonga et al., 2018). Although somatic embryogenesis has been obtained for many conifer species, it has achieved an industrial level of propagation with only a few (Park et al., 2016). However, clonal propagation from mature trees in vitro still remains a problem in some forest tree species, mainly in conifers; but in angiosperms micropropagation has been achieved from mature trees. Therefore, rejuvenation of organs/tissues from recalcitrant mature trees is a necessary prerequisite for clonal propagation in vitro, and has been accomplished in some tree species. Subsequently much progress has been made in the culture of tissues, organs, cells, and protoplasts in tree species. Tree Biotechnology has been making rapid progress in clonal propagation by organogenesis and somatic embryogenesis (Bonga and Durzan, 1987; Ahuja, 1993a; Park et al., 2016). Genetic control of differentiation and genetic stability of clones produced by organogenesis and somatic embryogenesis are important aspects of in vitro regeneration that need to be addressed in a clonal forestry program. Although there are limitations in cost-effective production of clonal propagules by organogenesis and somatic embryogenesis in forest trees, constructive and realistic biotech approaches are underway to overcome the limitations for large scale plantations of micropropagated clonal trees.

In this review, I shall discuss tree biotechnology and climate change in the framework of clonal propagation, genetic engineering in trees, and clonal forestry and genetically modified trees facing climate change. I shall briefly describe that some of the tree clones are ancient, and have been there for thousands of years (so-called Methuselah), and then discuss clonal forestry by vegetative propagation (macropropagation), and micropropagation. This will be followed by genetic transformation and confined field trials of transgenic trees, and finally I will discuss strategies for mitigation of global warming and adaptation of clonal forestry and transgenic forestry to cope with climate change.

\section{Ancient and potentially immortal clones}

Some of the forest trees have long life spans of thousands of years, and have become Methuselah trees. The oldest living forest trees in the world are the bristlecone pines (Pinus longaeva) first described to be 4845 years old (Schulman, 1958), but later revised to be 5062 years old by 2012 (www.rmtrr.org/ oldlist.htm). The family Cupressaceae has also some of the oldest living conifers. These include 3622 years old alerce $(2 n=4 x=44)$ (Fitzroya cupressoides), 3266 years old giant sequoia $(2 \mathrm{n}=22)$ (Sequoiadendron giganteum), and 2200 years old hehaploid coast redwood $(2 n=6 x=66)$ (Sequoia sempervirens) (see www.rmtrr.org/oldlist.htm). Whereas in Sequoia sempervirens vegetative propagation occurs naturally from stump sprouts and burls (O'Hara et al., 2017), other Methuselahs in this group do not normally clonally propagate in nature by vegetative propagation. However, there are tree species that have produced ancient clones that are thousands of years older than these Methuselahs.

Natural clones of some forest trees have been around for thousands of years, and in a sense, clones of such trees may be considered potentially immortal! There are a number of plant species in which ancient clonal colonies have survived for thousands of years. One of the oldest living clone is known as "Pando" (a Latin name meaning "I spread"). This ancient clone of quaking aspen (Populus tremuloides) belongs to the family Salicacecae, and its age has been estimated to be around 80,000 to $1,000,000$ years. The Pando clonal colony is located in the Fish Lake National Forest, north of Bryce Canyon National Park in central Utah. Vegetative propagation occurs in aspens from root suckers (or basal sprouts). Pando's clonal colony is world's largest and massive known organism, and has about 47,000 tree trunks, each with a normal complement of leaves and branches. Pando covers 43 hectares (106 acres) of the forest area (Grant et. al., 1992; Grant, 1993; Mitton and Grant,1996). Pando originated from a male tree and its clonal colony shares the common root system, and the same genetic constitution (DeWoody et al., 2008); and Pando most likely is a triploid $(2 n=3 x=57)$ clone (Mock et al. 2008; DeRose et al., 2015). Triploidy is widespread in aspens, and the three genomes in triploids compared to two in diploids aspens, may offer distinct advantages (heterozygosity, improved growth, and reproduction by vegetative means) for the survival of diversity in Pando genets in different environmental conditions (DeRose et al., 2015; Greer et al., 2017).

Another ancient forest tree clone belongs to a disjunct population of Palmer's oak (Quercus palmeri), belonging to the family Fagaceae, is located in the Jurupa mountains of Riverside county in California. Based on annual ring counts from a number of stems, the age of this clone was estimated to be around 13,000 years. This ancient oak species presumably spouted from a single acorn during Pleistocene, and has continued to clone for the last thousands of years (May et al., 2009). This ancient clone shows morphological homogeneity, allozyme polymorphism, and fire induced sprouting all support the hypothesis that Palmer's oak is a single ancient clone (May et al. 2009). Widespread fruit abortion suggests that Palmer's oak may be an ancient triploid clone. The current status of this 
species is categorized as threatened, and may become extinct in the near future.

Although spruces do not normally reproduce by vegetative means, there is an exceptional Norway spruce (Picea abies), belonging to the family Pinaceae, that also seems to be an ancient clone. This Norway spruce clone was nick-named by Leif Kullman (2008) as "Old Tjikko" after his late dog (Siberian Husky) and considered to be many thousand years old. This ancient Norway spruce clone is about 5 meters $(16 \mathrm{ft})$ tall, and is located in the Fulufället Mountains of Dalmarna Province of Sweden. This ancient clone has survived for thousands of years due to vegetative cloning. The present visible tree is relatively young, around 600 years old, but it is a part of a much older root system. The trunk of this clone may live up to 600 or more years, and when it dies, another trunk grows back in its place from the old root system by a process of layering. According to Kullman, heavy snow can bring branches close to earth, and new shoots can sprout from the contact point. Fossil wood pieces and cones have been recovered from this ancient clone, and their carbon dating suggests its age to be around 9,500 years, and they have the same genetic constitution as the root system (Olberg and Kullman, 2011).

Global warming is playing roulette with forest tree refugia from northern Hemisphere as they are moving poleward for genetic adaptation. However, how well will these refugia adapt to their new environment remains largely unknown. Although ancient clones are uncommon in the members of the family Pinaceae, more recently ancient clone has been found in larch (Larix spp). Larches are native to most of the temperate regions of northern hemisphere. Larches are among the dominant trees in the boreal forests of Siberia and Canada. One of the refugia is Dahurian larch (Larix gmelinii) is growing at a favorable site in the southern Taimyr Peninsula located in northcental Siberia. Although larches can reach an age up to 609 years in Siberia when growing as upright trees (Abaimov, 2010), and up to a 1000 years for North American species (Larix lyallii) (Arno and Habeck, 1972). Other individuals from the family Pinaceae attain ages of thousands of years. But most of them are not ancient clones.

Kruse et al., (2020) analyzed 16 nuclear microsatellite markers in 194 larch individuals to determine their genotypes. The age of the individual genotypes was determined by counted the tree rings. Their findings suggest that majority of the individuals in their study belong to genetically identical groups, and the predominant mode of reproduction was clonal as evidenced by short distance spreading of ramets. Clonal propagation was achieved by lateral growth/layering of spreading braches at the ground level. Based on tree rings the age it was determined that the clones were at least 2,200 years old, and these larch clones have survived the harsh climate of Tundra for hundreds and thousands of years (Kruse et al., 2020).

King's Holly (Lomatia tasmanica) is a small tree usually between 2-4 meters tall, but sometimes reaching a height of 6-8 meters, is a native shrub-tree of Tasmania. It belongs to the family Proteaceae. The population of Lomatia tasmanica occurs over a distance of $1.2 \mathrm{~km}$, and consists of several hundred stems. Genetic studies, based on allozyme analysis, indicate that Lomatia tasmanica is an ancient clone and possibly one of the oldest living plants approximately 43,000 years old (Lynch et al., 1998). The chromosome counts in the somatic cells indicate that Lomtia is a triploid $(2 n=3 x-33)$, compared to four other of Lomatia which are diploid $(2 n=22)$. The entire population of this species may be composed of one genet, as fruit production has not been observed. Lomatia regenerates continuously by root suckering (Lynch and Balmer, 2004). It has been postulated that Lomatia tasmanica is a hybrid originating by hybridization between Lomatia polymorpha and Lomatia tinctoria (Lynch et al., 1998).

In a changing world environment, many species are under considerable pressure to evolve, or face the extinction risk. clonal plants would be at a disadvantage, because of their narrow genetic base and genetic homogeneity, limited mobility, and capacity for adaptation. So how have these ancient clones survived and outlived the previous environmental changes, and persisted over the millennia. One possible hypothesis suggests that gene regulation through epigenetic mechanisms (changes) might provide the optimum phenotypic variation for clonal spread, adaptation and survival in a changing climate (Douhonikoff and Dodd, 2015; Dodd and Douhonikoff, 2016). Another possibility may be the presence of triploidy in certain plant species that can propagate in nature by asexual methods. The advantage of triploidy lies in its heterozygosity, that buffers the effect of gene redundancy on mutations, and triploids generally exhibit vigorous vegetative growth. And in certain cases, as in the ancient aspen clone Pando, Palmer's oak clone, and King's Holly clone, their survival is seemingly further facilitated by vegetative propagation.

\section{Regeneration and clonal forestry}

Clonal forestry involves production and use of vegetative propagules by vegetative propagation. Clonal propagation has been achieved by macropropagation or micropropagation. Vegetative propagation by macropropagation involves traditional vegetative propagation techniques, while micropropagation is carried out by tissue culture technology.

\section{Macropropagation}

In the past several decades serious consideration has been given to genetic improvement of forest tree species. This involves hybridization between superior individuals and then establishment of seed orchards. In order to achieve genetic gain in forest tree species, it would be necessary to cross breed elite trees for at least a few generations, each requiring anywhere from 10 to 50 years. One way to capture genetic gain more readily in the same generation is to clonally propagate selected genotypes by vegetative means. In this respect, clonal forestry has certain distinct advantages over zygotic forestry. Clonal forestry involves efficient management and increase of genetic gain by selection and maintenance of additive and non-additive gene effects. On the other hand, through sexual reproduction only additive gene effects can be utilized; the non-additive gene effects arising from interaction of genes are not normally transmitted through generative reproduction (Ahuja and Libby, 1993a). The non-additive gene effects can give rise 
to exceptional individuals within superior families (in outcrossed plants, such as forest trees), and these can be captured along with additive gene effects by vegetative propagation, or by crossing homozygous individuals. Clonal forestry is not new. Vegetative propagation has been part of the evolutionary history of herbaceous plants and forest trees, and ancient clones have existed for thousands of years.

\section{Micropropagation}

Regeneration of forest trees has been routinely achieved by organogenesis and somatic embryogenesis. Genetic control of regeneration and morphological and genetic stability of regenerants by organogenesis and somatic embryogenesis have been investigated in a number of forest tree species.

In vitro regeneration potential of tissues depends on several parameters. These include tissue source (axillary bud, nodal segment, cotyledon, zygotic embryo, shoot tip, bud meristem), physiology, developmental stage, time of the year explants cultured, age of the donor and genotype of the donor trees, and media composition and in vitro environment.

The use of regeneration technology in forestry offers prospects for: (1) manipulation of the mature state of tissues, (2) germplasm preservation by long-term in vitro cultures, and cryopreservation, and (3) somaclonal variation for isolation of useful genotypes, and (4) gene transfer and production of transgenic trees.

Although, somaclonal variation in trees is usually undesirable (Tremblay et al., 1999; Breton et al. 2006; Marum et al., 2009), a few useful somaclonal variants have been reported in tree species (Ahuja, 1998; Bairu et al., 2011; Krishna et al., 2016). Some of these useful variants include: height and morphological traits in poplar (Fry et al., 1997) and olive (Leva et al., 2012); disease resistance in poplar (Ostry and Ward, 2003), apple citrus, and mango (Krishna et al., 2016); different growth rates in poplar (Gamburg and Voinikov, 2013); and stress tolerance in radiata pine (Montalbán et al., 2014).

These regeneration studies have paved the way for genetic transformation and production of transgenics carrying a variety of transgenes that code for herbicide tolerance, insect resistance, lignin modification, increased woody biomass, and reproductive manipulation, in a number of different forest tree species. Clonal forestry and transgenic forestry have come of age. However, more research is needed for their application in forestry.

\section{Micropropagation from mature trees}

We have employed tissue culture technology for rapid clonal propagation of a number of forest tree species. Our aim was to optimize cost-effective protocols for micropropagation of selected genotypes, whose clones exhibited phenotypic and genetic stability not only in greenhouse, but also under field conditions. The second objective was to find out the ability of the propagules of an introduced species to adapt to a new environment. In both cases phenotypic and genetic fidelity of clones was also an important consideration. Here I shall focus on micropropagation of selected trees of aspens (Populus tremula, P. tremuloides, and their hybrids), and coast redwood
(Sequoia sempervirens) introduced into Germany for its ability to survive under temperate and cold climates. We have employed direct organogenesis for micropropagation of mature trees.

\section{Populus-Aspens}

At the Thuenen-Institute of Forest Genetics at Grosshansdorf, Germany, elite genotypes had been selected in European aspen $(2 n=38)$ (Populus tremula) and quaking aspen $(2 n=38)(P$. tremuloides), and their hybrids $(2 n=38)$ following controlled crossings between European aspen and quaking aspen ( $P$. tremula $\times$ p. tremuloides) (Melchior, 1985). The hybrid aspens have exhibited good form and growth under field trials (von Wuehlisch and Ahuja, unpublished). Aspens are difficult to propagate vegetatively by woody stems cuttings, because of lack of preformed root primordials. On the other hand, poplars can be easily propagated by stem cuttings (hardwood cuttings), which root readily in soil or peat-perlite substrate. However, aspens can be vegetatively propagated by root suckers, grafting, and juvenile green shoots. Because of cost factors, propagation by grafting, green shoots, and root suckers had limited commercial applicability in the aspen regeneration programs. For this reason, aspens have so far been mostly propagated by seed (zygotic forestry). However, tissue culture technology offered prospects of rapid large scale micropropagation of aspens. We (Ahuja and Muhs, 1985) undertook clonal propagation by organ culture of selected mature aspen and hybrid aspen genotypes by direct organogenesis by tissue culture technology.

Dormant buds from 17 to 40 years old aspen and hybrid aspen were collected during winter months and stored at $0 \circ \mathrm{C}$. Bud meristems from more than 100 aspen and hybrid aspen clones were cultured in Aspen Culture Medium (ACM) (Ahuja, 1983), which is a slightly modified version of Woody Plant Medium (WPM) (Lloyd and McCown (1981) for their regenerative potential. Initially, a 4-step micropropagation method (Ahuja, 1983) was employed for clonal propagation of aspens (Fig. 2, 4-step method). This method consisted of: (1) Bud break and conditioning of bud meristems in ACM-1 (ACM + $20 \mathrm{mg} / \mathrm{l}$ adenine sulfate $+0.5 \mathrm{mg} / \mathrm{lBA})$, (2) growth proliferation in ACM$2(A C M+0.2 \mathrm{mg} / \mathrm{l} \mathrm{BA}+0.02 \mathrm{mg} / \mathrm{l} \mathrm{NAA})$ (Fig. $1 \mathrm{~A})$, (3) rooting of microshoots in ACM-3 (ACM + $0.5 \mathrm{mg} / \mathrm{l} \mathrm{IBA}+0.1 \mathrm{mg} / \mathrm{l} \mathrm{NAA})$ (Fig. $1 \mathrm{~B}$ ), and (4) transfer of plantlets derived from $A C M-3$ to pots (after sloughing off agar from the roots) for hardening and acclimatization in controlled chambers and greenhouse (Ahuja 1983, 1986, 1987). 


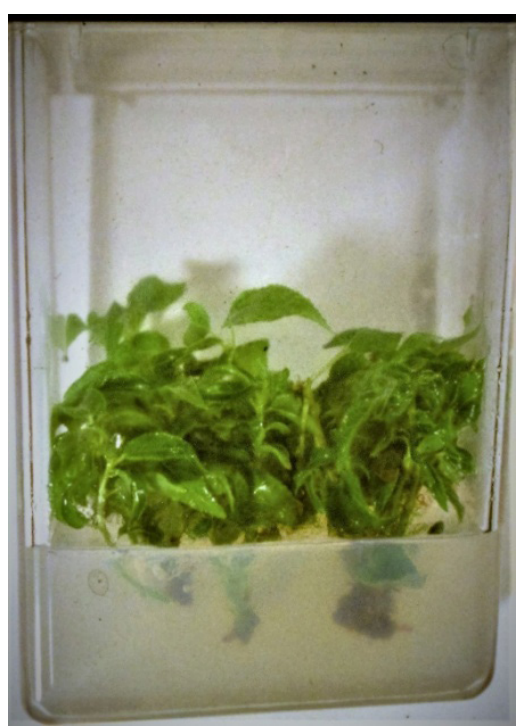

A

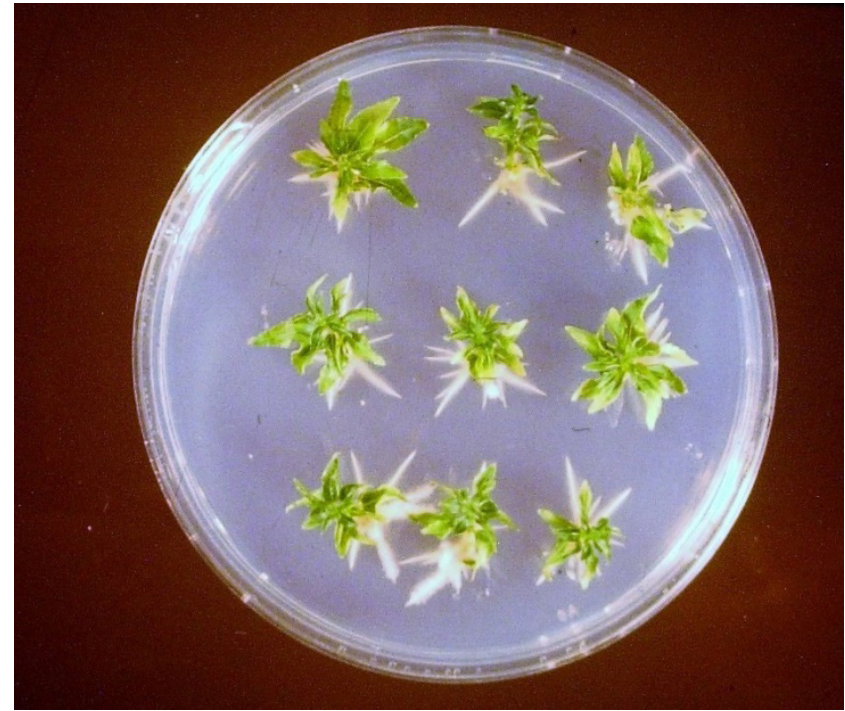

B

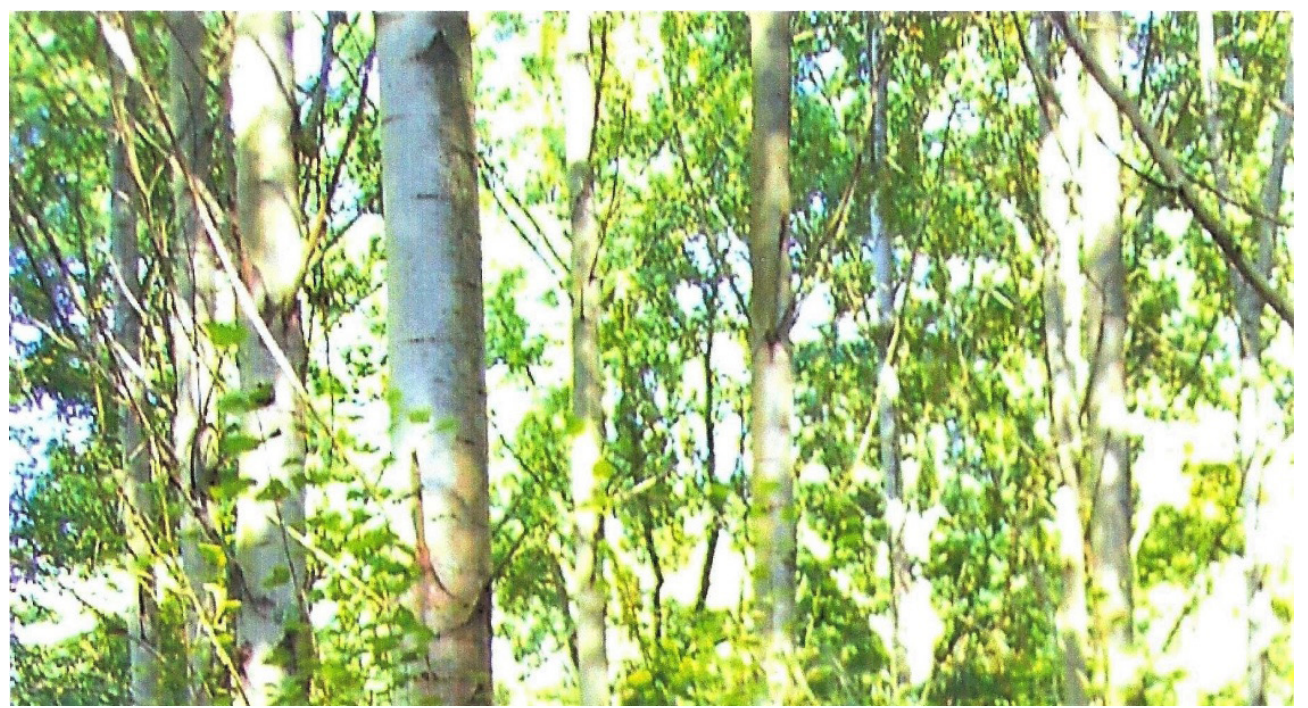

C

Fig. 1

Microshoot regeneration in Hybrid aspen in the culture medium ACM-2 (A); plantlet regeneration in the culture medium ACM3 (B), and 25 years-old hybrid aspen trees produced by tissue culture in field trials in northwestern Germany (C)

Subsequently, the 4-step method was simplified so as to reduce the number of steps to make the micropropagation method cost-effective (Fig. 2). First the 4-steps were reduced to three, by eliminating step 1, and accomplishing both meristem conditioning and shoot proliferation on ACM-2, without any appreciable impact on growth and differentiation (Fig. 2, 3-step method). Later step-3 (ACM-3) was also eliminated from the scheme, and microshoots were rooted directly in 


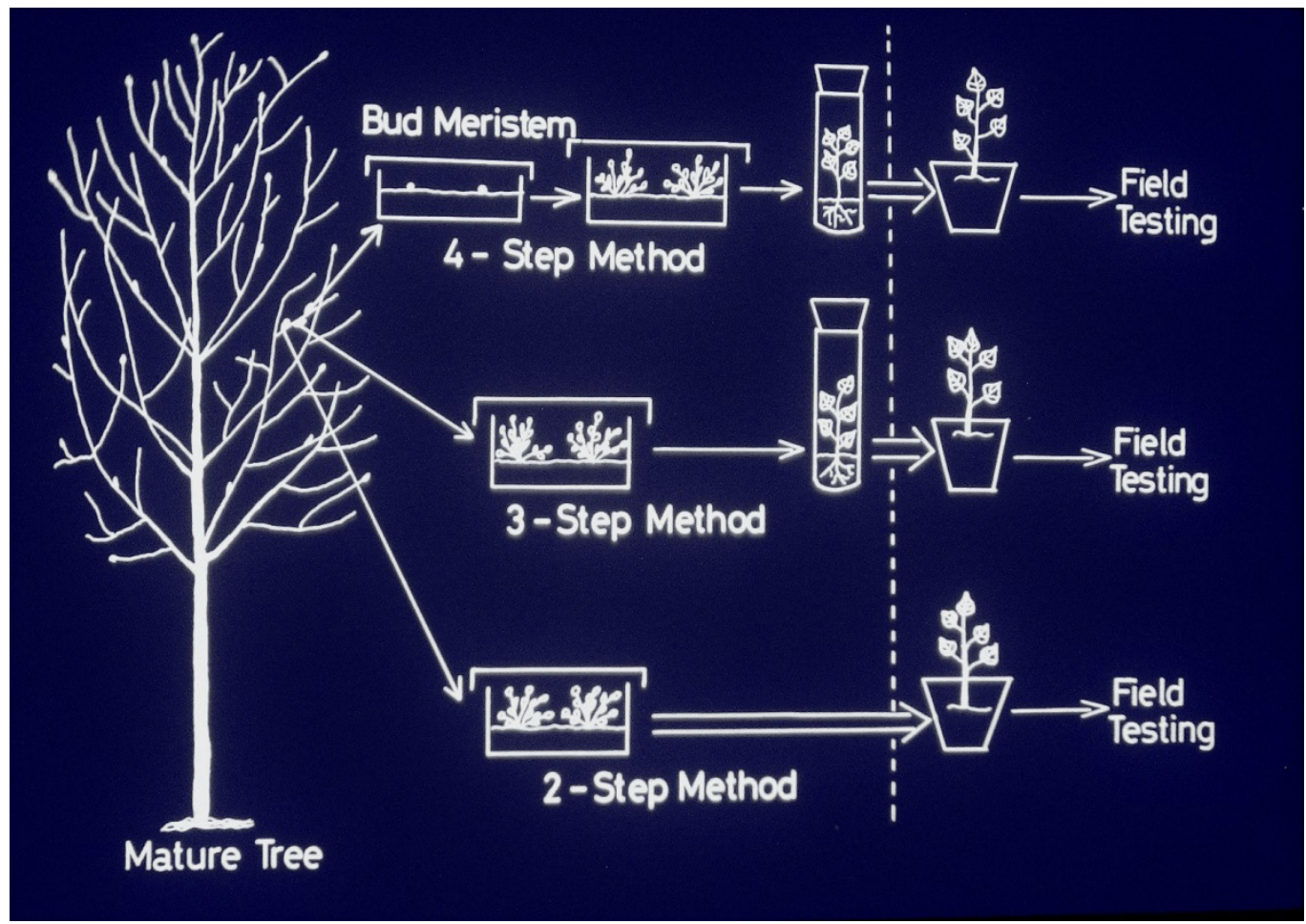

Fig. 2

Diagrammatic representation of 4-step method, 3-step method, and 2-step method for micropropagation of aspen clones from mature trees. By simplification of this procedure from 4-step to 2-step protocol, it is possible to reduce costs for clonal propagation (From Ahuja amd Muhs, 1985)

once autoclaved soil-free potting mixture under high humidity controlled environment (Ahuja, 1984). Thus, it was possible to evolve a 2-step micropropagation procedure (Fig 2, 2-step method) from the original 4-step method, not only to reduce costs, but also to minimize the exposure of tissues to prolonged cultural conditions for minimizing somaclonal variation. There was a very little or negligible amount of callus formation in our direct organogenesis method for micropropagation. The micropropagated aspens showed phenotypic and genetic stability when grown under greenhouse and field conditions (Ahuja, 1983, 1987, 1993b). We have randomly checked chromosome numbers of some of the microprogated plants. Aspens have a diploid chromosome number of $2 n=38$, and our tested plants had the same genetic diploid constitution (Ahuja, 1984). By employing the 2-step micropropagation method, we regenerated several thousand plantlets from more than 30 selected mature aspen and hybrid aspen clones. Twelve hybrid aspen clones have been approved under the category "Tested Material" in the multiclonal variety 'Grosshansdorf', Germany. We have established a number of field trials for testing micropropagated aspens and hybrid aspen clones, along with zygotic seedlings, and some of these are now more than 25 years old (Fig. 1, C) and are still undergoing phenotypic and genotypic evaluations (von Wuehlisch and Ahuja, unpublished).

Initial data from 48 clones revealed that regeneration of shoot differentiation was achieved in about half ( 22 of 48 ) of the clones tested (Ahuja, 1983). Subsequently, additional data on 70 aspen clones also revealed that half (37 of 70) tested showed good microshoot differentiation (Ahuja, 1984). Similarly, there was a 1:1 segregation in 39 clones (17 of 39) for shoot differentiation vs. no differentiation in the female and male hybrid aspen clones (Ahuja, 1993b). Genetic control of microshoot differentiation by organogenesis and somatic embryogenesis in tissue cultures were also observed in both angiosperm (Wann and Einspahr, 1986; Coleman and Ernst, 1989; Coritzo et al., 2009; Erst et al., 2014), and conifer (Klimaszewska et al., 2007; Trontin at al., 2016) tree species.

\section{Coast redwood (Sequoia sempervirens)}

Coast redwood (Sequoia sempervirens) is an interesting and unique conifer. Sequoia is a long-lived conifer belonging to the family Taxodiaceae, (now included under Cupressaceae). It has the world's tallest trees, one measuring $113 \mathrm{~m}$ in height (Koch et al. 2004). However, recently another Sequoia tree called Hyperion, which measured $\sim 115 \mathrm{~m}$ in height, has become the tallest tree in the world (Sillett et al., 2015). Sequoia is the only conifer that is hexaploid $(2 n=6 x=66)$, and origin of its enigmatic polyploidy still remains unresolved. It is not known when the polyploidy Sequoia evolved from its diploid ancestors, and which really are its putative progenitors (Stebbins, 1948; Ahuja and Neale, 2002; Ahuja, 2009). Sequoia reproduces by both sexual (seed) and vegetative methods (from basal sprouts and 


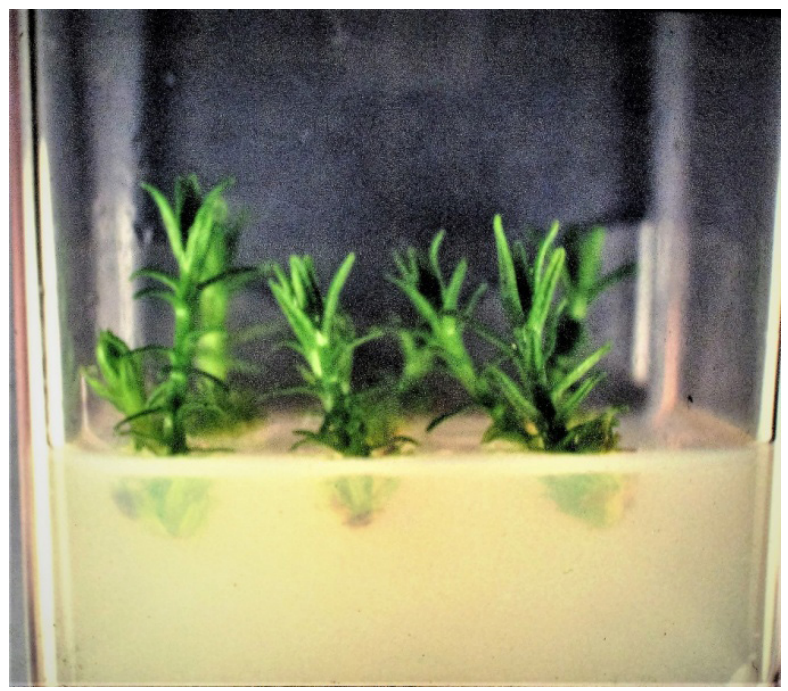

A

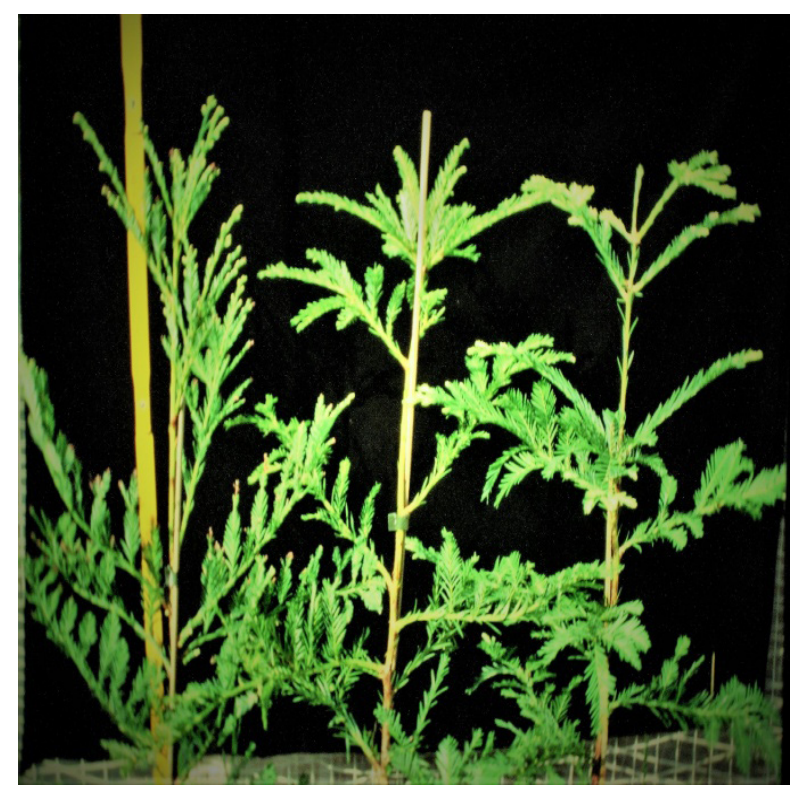

C

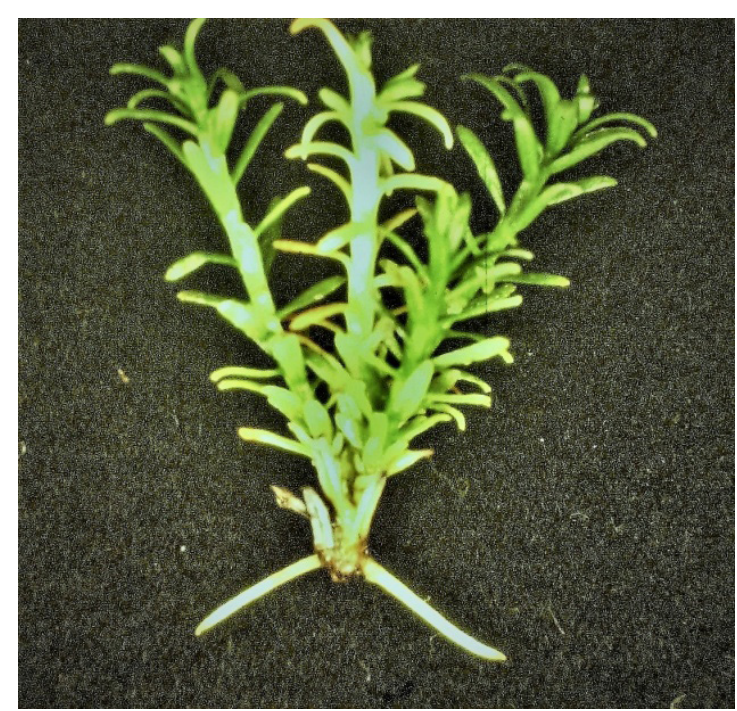

B

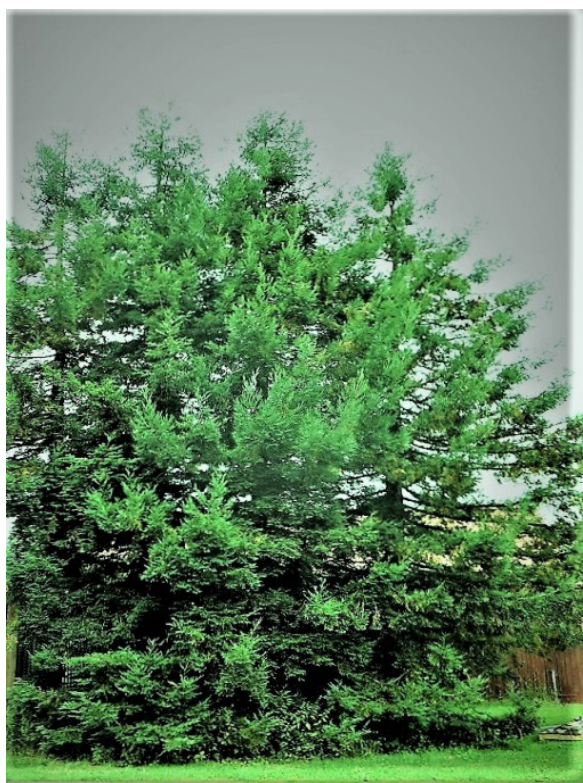

D

Fig. 3

Micropropagation of Sequoia sempervirens showing microshoots (A), and rooted plantlet (B). Greenhouse grown micropropagated plants (C), and more than 25 years old frost-tolerant Sequoia trees (photograph by Dr. Georg von Wuehlisch) in the arboretum (D) of Thuenen-Institute of Forest Genetics, Grosshansdorf, Germany

burls) to maintain heterozygosity and adaptability for survival. It is a resilient conifer that presumably originated as a polyploid from its putative progenitors most likely during Cretaceous and Tertiary periods ( 135-65 mya) (Ahuja, 2005, 2009a). Sequoia is an endemic restricted in its natural habitat to the fog belt of California and southern Oregon, USA. It grows from sea level to $900 \mathrm{~m}$ altitude, but prefers altitudes lower than $750 \mathrm{~m}$, in a frost-free period ranging from 6-11 months in a year (Olson et al. 1990). Because of its polyploid nature, meiosis is irregular and seed set is low in Sequoia, varying from 1-10\%, and only $5-10 \%$ of the seeds are viable (Olson et al., 1990; Ahuja and Neale, 2002; Ahuja, 2005). Although older Sequoia trees (genotype dependent) are relatively less susceptible to frost, seedlings in the Pacific Northwest region, where 
Sequoia is an endemic, are vulnerable to infection by a fungus Botrytis and frost damage (Olson et al., 1990). For this reason, clonal forestry offers prospects for propagating selected genotypes by tissue culture.

Sequoia has been grown out of its endemic region with varying degrees of success in different parts of the world, including France, Germany, Spain, United Kingdom, Turkey, Chile, South Africa, and New Zealand (Kuser et al., 1995; Meason et al., 2016; Klápště et al., 2020).

Micropropagation has been achieved in Sequoia by using meristems, nodal stem explants, and needles of juvenile explants, as well tissues from stump shoots of mature trees that were 90 years old (Boulay, 1978; Ball et al., 1978; Arnaud et al., 1993; Bon et al., 1994; Sul and Korban, 2005; Korban and Sul, 2007). Somatic embryogenesis and organogenesis was also reported by tissue culture of needles of Sequoia (Liu et al., 2006). In general, stump shoots from the base of mature Sequoia trees are more responsive to in vitro regeneration compared to shoots from the crown of the same mature trees.

During the winter of 1985-1986, a Sequoia plantation near Cologne, Germany was badly hit by the frost and extremely low temperature around $-15^{\circ} \mathrm{C}$. A number of trees survived the winter. The owner of the plantation sent branches from three (two 25 years old, and one aged 8) frost-tolerant Sequoia trees, to the Thuenen-Institute of Forest Genetics, Grosshansdorf, for clonal propagation and to test their ability to tolerate frost in Germany. We cultured bud meristems from the three trees on a modified woody plant medium fortified with low concentrations of BAP ( 0.2 to $0.5 \mathrm{mg} / \mathrm{l})$ and NAA ( $0.02 \mathrm{mg} / \mathrm{l})$ (Fig. $3 \mathrm{~A})$, and rooted microshoots (Fig. $3 \mathrm{~B}$ ) in a hormone-free medium, and ex vitro in a peat-perlite potting mixture, and later the young plants were grown in the greenhouse (Fig. 3 C) (Ahuja, 1996, 2011a). More than 1000 plants were produced from the three trees by tissue culture, and several hundred clones were tested under field conditions for testing their overwintering capacity. Field trials from the clones derived from three frost-tolerant trees were conducted for a number of years at Grosshansdorf and Trenthost, in northern Germany. Trees in Grosshansdorf arboretum seem to be frost-tolerant and have survived more than 25 winters in Germany (Fig. 3 D). However, under field conditions at Trenthorst, only those clones survived that were sheltered by a tree canopy towards the edge of the field. Therefore, sheltering of Sequoia clones derived from frost-tolerant trees were necessary during several years of their early growth period for their later survival in harsh winters in temperate climate zones (Ahuja, 1996, 2011a, 2017).

Based on these regeneration studies on forest trees, it is suggested that an ideal method for micropropagation should have the following criteria (modified from Ahuja, 1987):

- It is relatively simple,

- Gives high frequency microshoot multiplication rate,

- Has a high degree of reproducibility,

- Applicable to juvenile and mature tissue,

- Applicable to different genotypes
- Induces direct differentiation of microshoots, or somatic embryos, with minimum callus formation,

- Gives high frequency of plantlet formation in vitro, or ex vitro,

- Gives high survivable of plantlets or somatic embryos after potting and transfer to greenhouse,

- Easily adaptable to greenhouse and nursery conditions for acclimatization,

- Ensures, to a large extent, genetic stability of propagules under in vitro environment, ex vitro greenhouse, nursery and field conditions, and in progeny tests,

- Most importantly, it is cost effective, that is, costs of microp ropagated plantlets or somatic embryos are comparable to zygotic seedlings.

Although such an ideal method of micropropagation is not yet available for organogenesis or somatic embryogenesis for forest trees, at least some aspects of such a procedure have been accomplished in Populus and some other tree species. And major biotech efforts are progressing rapidly for making clonal forestry by micropropagation commercially feasible.

\section{Genetic engineering in trees}

Although genetic improvement of forest trees has mainly progressed by selection and breeding methods (Zobel and Talbert, 1884; White et al. 2007; Neale and Kremer, 2011; Eriksson et al., 2013), these approaches have limited applicability in long-lived forest trees, with extended vegetative phases ranging from one to many decades. Genetic engineering (GE), on the other hand, offers prospects of transfer of desirable genes into selected genotypes at a comparatively faster rate by bypassing the prolonged breeding process. Thus, transfer of genes with desirable traits by traditional approaches, involving breeding and recurrent selection would that take decades to centuries in forest trees, can be accomplished by genetic engineering in a single generation. Furthermore, GE overrides incompatibility barriers and allows gene transfer not only in unrelated tree species, but also between widely divergent taxa. At the same time GE also removes potentially undesirable effects of linked alleles to transferred genes which could be inadvertently introduced to the progeny by conventional breeding programs (Ahuja, 2009b, 2011b).

After establishing well defined regeneration systems, both by organogenesis and somatic embryogenesis, it became possible to transfer recombinant genes in forest trees by GE. Ever since the first report on the Agrobacterium-mediated transfer of herbicide tolerant gene to poplars (Fillatti et al., 1987), there has been considerable interest in the application of GE to forest trees by Agrobacterium-mediated or biolistic methods. During the last three decades, a number of forest trees have been genetically engineered with a variety of different recombinant genes, using tissues derived from organogenesis (leaf discs, microshoots, different tissues/organs) and somatic embryogenesis (embryonal cells/mass) for the production of transgenic trees (Charest and Michel, 1991; Fladung, Muhs, Ahuja, 1996; Ahuja, 2000; Trontin et al., 2002, 2007; Tang and Newton, 2003, Charity et al., 2005; Klimaszewska et al., 
2007; Lee et al., 2014; Uddenberg et al., 2016). The first wave of GE involved the transfer of "foreign" genes (mostly bacterial genes) used as reporter genes to monitor the integration and expression of transgenes in forest trees. This was followed by a second wave which included transfer of economically important genes for herbicide tolerance, pest resistance, lignin modification, yield traits, and reproduction manipulation (both bacterial and plant genes) to the forest tree genome (Ahuja, 2001, 2009b, 2011b, 2014a; Boerjan, 2005; Brunner et al., 2007; Hoenicka et al., 2012; van Acker et al., 2014; Chang et al., 2018; Klocko et al., 2018; Bruegmann et al., 2019a). However, there were a number of technical problems and limitations to in vitro regeneration of selected genotypes in forest trees. Some of these problems have been addressed and progress has been made and genetically modified forest trees are undergoing confined field testing of their growth performance and biosafety (Häggman et al., 2013; Porth and El-Kassaby, 2014; Ahuja, 2014a, 2014b; Vettori et al., 2016).

\section{Transgene stability}

Forest trees have long generational cycles with vegetative phases extending from one to several decades. Genetic and phenotypic stability of genetically modified trees are important considerations for subsequent large scale plantations of GE trees (Ahuja, 1988b, 1997, 2000; Hawkins et a., 2003; Hoenicka and Fladung, 2006a; Brunner et al., 2007; Porth and El-Kassaby, 2014). In addition, the potential risk concerning escape of transgenes from GE trees, horizontal gene transfer, vegetative propagation capacity of root suckers (for example, in aspen), effect of GM trees on target species, and effects of GM trees on non-target feral tree populations acquiring the transgens needs to be addressed before commercial deployment of GE trees can begin (Brunner et al., 2007; Farnum et al., 2007; Smouse et al., 2007; Ahuja, 2009b, 2011b, 2014a). Because integration of transgenes in the genome of host-plants occurs randomly and at non-predictable genomic sites, variable transgene expression could be one of the consequences. Other possible consequences are putative disruption leading to knock-out or even over-expression of host-genes (Fladung et al., 2005). One possible solution could be the targeted integration of foreign genes into so-called "safe-heavens" of the host genome by the application of site-specific recombination systems, which has been successfully tested in poplars (Fladung et al., 2010; Fladung and Becker, 2011).

Stability of transgenes in the vegetative propagules and across reproductive generations, and transgene containment are important considerations for long-lived forest trees that will ultimately determine their future in forestry (Ahuja, 2009b, 2011 b; Ahuja and Fladung, 2014). Stability of transgene expression and functional utility of a transgene in time and space in the forest tree genome are also important considerations for transgenic research (Ahuja 2000). As trees grow, they increase in size and complexity with their increasing age, and changes in gene expression are likely to occur during seasonal cycles and in a changing environment. Therefore, promoter fidelity and genetic stability of transgene expression have to be viewed at several different levels in the long-lived forest trees. In this context, the activity of some transgenes (for example, herbicide tolerance) may be required for a short duration during early growth, while others to remain active throughout the life (for example, pest resistance, lignin reduction, yield traits), and still others would be required at a specific time (for example, reproductive sterility) of the forest tree growth and development (Ahuja, 2009b, 2011b, 2014a).

Variation in transgene expression has been widely reported in transgenic herbaceous plants and forest trees. Variation in gene expression may be caused by somaclonal variation (Larkin and Scowcroft, 19981; Ahuja, 1987, 1998), integration patterns and copy number of a transgene, and inactivation/silencing of the transgenes in the host genome (Finnegan and McElroy, 1994; Ahuja and Fladung, 1996; Fladung et al. 1997; Ahuja, 1997; Kumar and Fladung, 2002; Butaye et al., 2005; Wagner et al. 2005; Ladics et al., 2015). Detailed studies have been carried out in Populus and several other forest tree species for determining the stability of transgenes on a short-term and long-term basis.

One study used the rolC gene from Agrobacterium rhizogenes, which is a dominant gene that affects the plant phenotype, particularly the leaf size and color when introduced in a plant. Since rolC gene expression can be monitored at the phenotypic level, it can be used as a selectable marker to assess its phenotypic and molecular expression, as well as genetic stability in the transgenic plants. The phenotypic effects of rolC gene have first been tested in the annual plant species tobacco (Nicotiana tabacum) (Spena et al. 1987; Schmueling, Schell, and Spena, 1988) and potato (Solanum tuberosum) (Fladung, 1990; Fladung and Ballvora, 1992).

A morphological marker has a distinct advantage, when compared to the time-consuming analysis of biochemical markers, such as $\beta$-glucoronidase (GUS) gene, at specific intervals, because it can be easily observed at all times during the life cycle of a transgenic plant. Four selected clones from aspen ( $P$. tremula) and hybrid aspen ( $P$. tremula $x P$. tremuloides) were genetically transformed by using the leafdisc Agrobacterium co-cultivation method. Two rolC reporter gene constructs with different promoters (35S::rolC an rbcS::rolC) were employed in this study, showing different leaf sizes (Fig. 4 A) (Ahuja and Fladung, 1996; Fladung et al., $1996,1997)$. Transgenic aspens carried 1-2 copies of the rolC transgene (Fig. 4 B). Transgenic lines carrying the rolC transgene were grown in the greenhouse for more than 19 years (Fladung et al., 2013), and in a confined field trial carried out for 5 years on the grounds of the Thuenen Institute of Forest Genetics, Grosshansdorf, Germany (Fladung et al., 2004; Fladung and Hoenicka 2012; Pilate et al., 2016). Variation in phenotypic expression was observed in a number of transgenic plants both in the greenhouse (Fig. 4 C, D) and field conditions (Ahuja, 2000; Fladung et al., 2004). Results from this study have revealed that most of the transgenic plants carrying a single copy of the transgenes were relatively more stable than, those carrying more than one copy of the transgene (Ahuja, 2000; Fladung and Kumar, 2002; Kumar and Fladung, 2002; Fladung, Hoenicka, and Ahuja, 2013). 

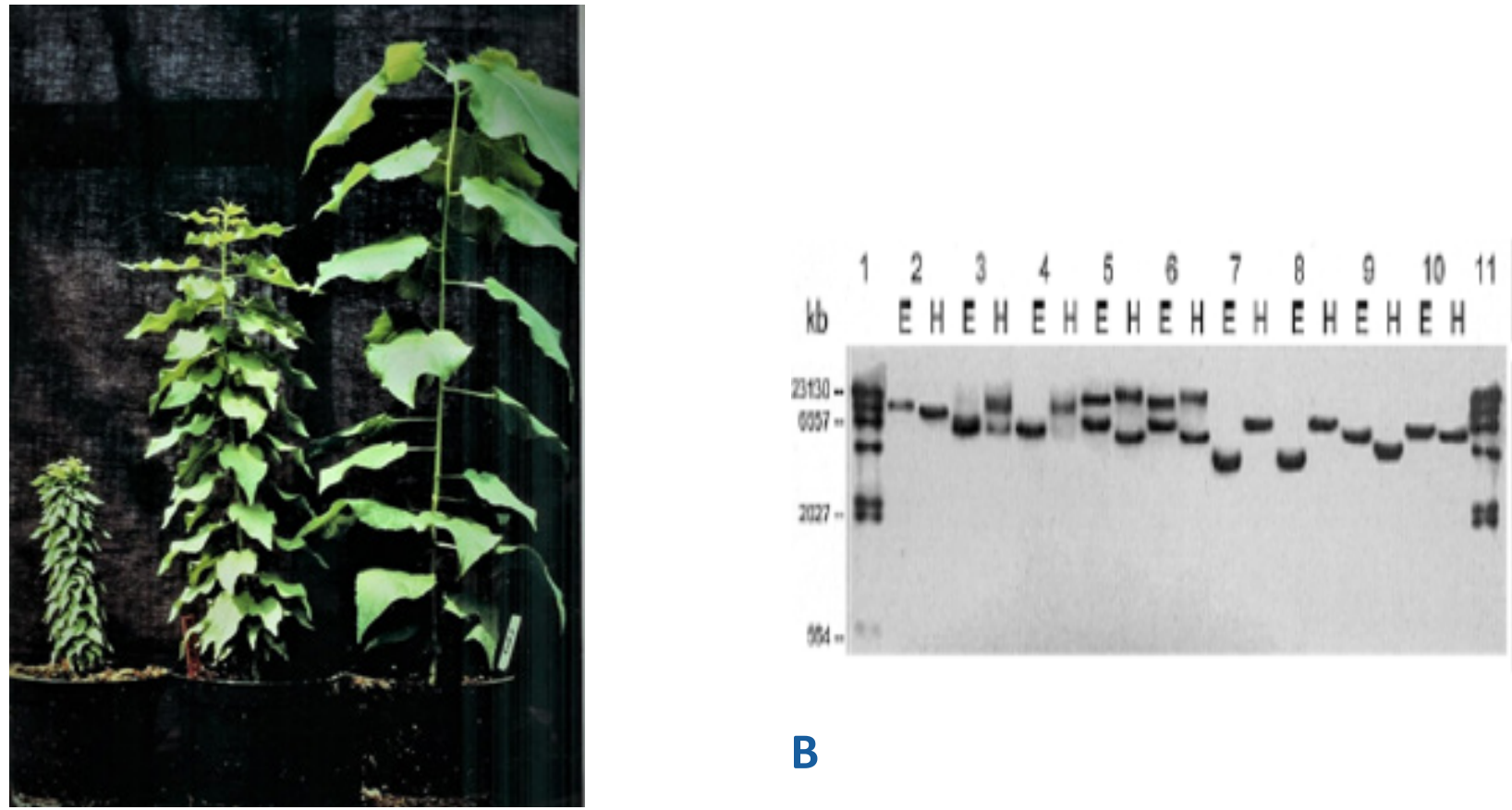

A

B

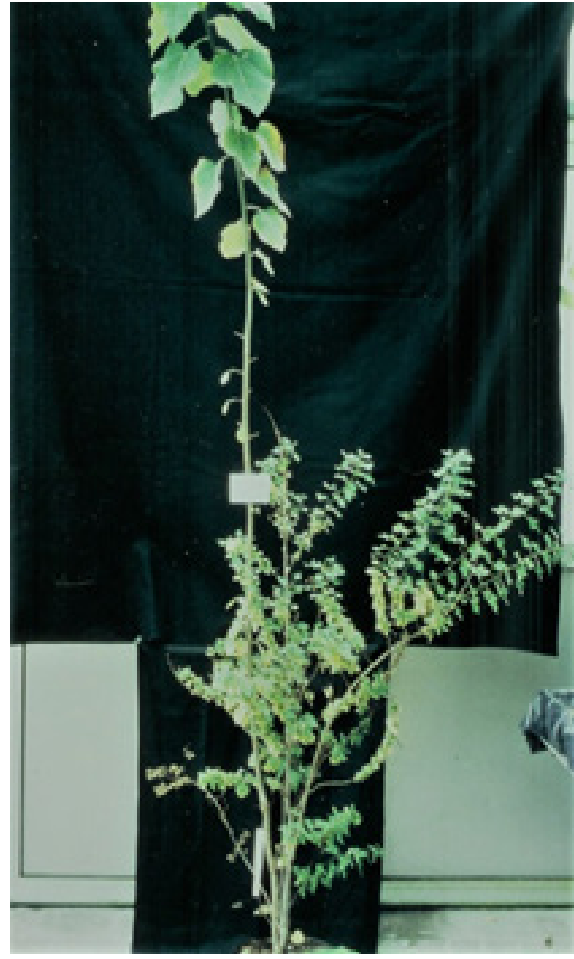

C

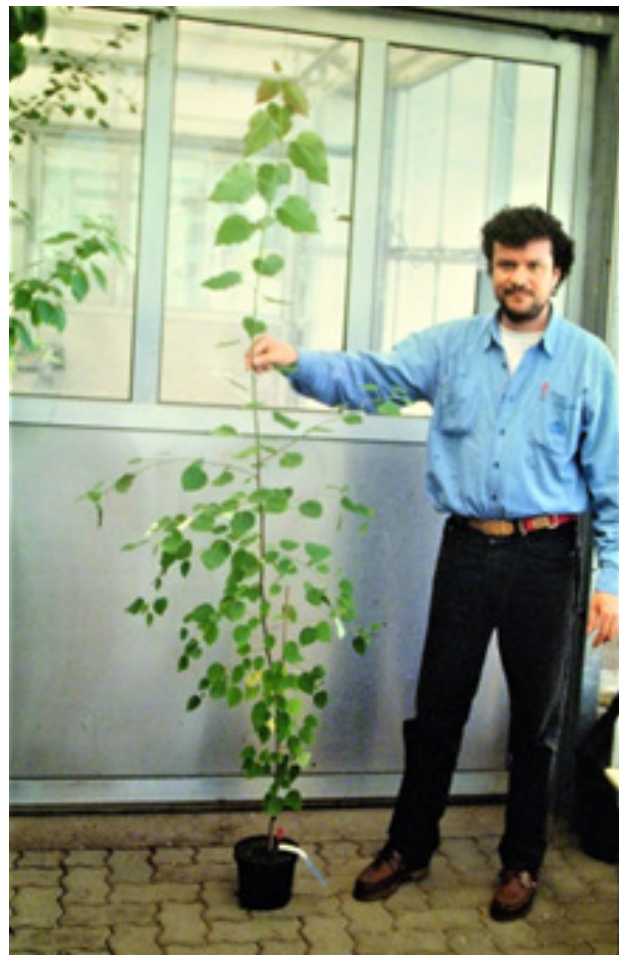

D

Fig. 4

Transgenic hybrid aspen clone Esch5 carrying two and one copies of the 35S::rolC (left, middle, respectively), along with a wildtype Esch5 clone (right), showing different sizes of leaves conditioned by the rolC gene (A); Southern blot showing one and two copies of the transgenes in transgenic hybrid aspen Esch5 clone (B). Bottom row shows chimeras in 35S::rolC transgenic hybrid aspen clone Esch5 (C), and Brauna 11 (D) carrying rbcS::rolC transgene" 
Detailed confined field studies, ranging from 3 to 8 years have also been carried out in genetically modified poplars and white spruce. Transgenic poplars showed relatively stable expression of the herbicide tolerant gene up to 8 years under confined field trials (Li et al., 2008). Genetically modified dwarf white spruce (Picea glauca) carrying the $B t$ gene (derived from soil bacterium Bacillus thurigiensis). Bt gene produces an insecticidal protein) also showed a continued insecticidal activity in confined field trials for 5 years (Lachance et al., 2007). Generally, stable expression of transgenes was detected with one or a few copies of transgenes in these studies (Brunner et al., 2007; Li et al., 2008). However, there were exceptions in another study, where one or fewer copies of a transgene were not always associated with stable expression of the transgene, as was reported in the antifungal transgene (pinosylvin synthase) activity in poplars (Seppänen et al., 2004).

Because of the randomness of transgene integration and instability in the Agrobacterium-mediated and biolistically transformed plants, a site-specific, and a highly efficient and precise gene integration strategy, involving CLUSTERD REGULARLY INTERSPACED SHORT PALINDROMIC REPEATS (CRISPR)associated protein9 (Cas9) genome editing system (CRISPRCas9) has been used for targeted mutagenesis in forest trees (Tsai and Xue, 2015; Fan et al., 2015; Zhou et al., 2015; Bruegmann et al., 2019b). CRISPR has become one of the most promising tool in genetic engineering, and offers the potential for substantial improvement over other gene editing technologies in its efficacy, speed and low cost. The power of the CRISPR-Cas9 platform lies not only in its ability to precisely engineer "foreign genes" (genes derived from other organisms) at specific locations in the host genome, but also native genes for the production of transgenic plants. Another utility of this gene targeting system lies in the potential for activating/ editing native plant genes for drought tolerance, frost tolerance, disease resistance and other qualitative and possibly quantitative traits, rather than introducing exogenous genes (derived from outside the host organism) for these traits. Such innovations will pave the way for next generation biotech crops/trees to be less regulated or not regulated by federal oversights, as these novel genotypes will be, more or less, substantially equivalent to genetically unmodified plants (Ahuja, 2014b). Although still in infancy, the CRISPR-Cas9 genome targeting system is evolving rapidly and seems to accomplish both gene insertion and gene mutation in plants/trees (Li et al., 2015; Ma et al., 2016; Tycko et al., 2016; Puchta, 2017; Sukegawa et al., 2021). The CRISPR-Cas9 gene targeting system also offers prospects for altering the genome in somatic embryogenesis or organogenesis cultures of forest tree species for genetic improvement and perhaps scaled-up, cost effective clonal forestry.

\section{Transgene containment and regulation}

Several approaches have been proposed to impede the escape and containment of transgenes (Brunner et al., 2007; Ahuja, 2011b; Hoenicka et al., 2012b). These include: (1) reproductive sterility and early flowering (Strauss et al., 1995; Hoenicka and Fladung, 2006b; Brunner et al., 2007; Traenkner et al., 2010;
Klocko et al., 2016, 2018; Briones et al., 2020), (2) site-specific excision of transgene mediated by recombinase systems, where the functional transgene is removed from the gametes before flowering (Luo et al., 2007; Gidoni et al., 2008; Fladung et al., 2010), and (3) introducing transgenes into the chloroplasts genome to reduced transgene escape via pollen (Bock 2006; Verma and Daneill, 2007). Transgene escape from transgenic populations is a virtual reality, and none of these approaches would likely achieve 100 percent transgene containment in the forest trees in a real world (Ahuja, 2009, 2011b; Ellstrand, 2018). Although, studies on containment of transgenes are being actively pursued, their successful application to forest trees, with extended vegetative phases, still remains a challenging problem. One alternative non-GE approach would be by isolating the transgenic populations to delimited areas, or using incompatible genotypes of wild tree populations neighboring the genetically modified trees (Ahuja, 2011b).

The commercialization status of genetically modified forest trees is presently at the crossroads. The future of genetically modified forest trees still remains controversial and uncertain, as a number of biological and regulatory issues relevant to transgenic trees need to be addressed and resolved before their commercial deployment (Ahuja, 2009b, 2011b, 2014a, Bradford et al., 2005; Finstad et al., 2007; Custers et a., 2016). Forest scientists view that the regulatory obstacles have hindered progress of transgenic forest biotechnology (Strauss et al 2009a). Until now the US regulatory requirements had focused on the insertion and integration of the foreign genes and possible genetic changes caused by the transgene (process), and not in the trait (product) itself in the host plant (Sederoff 2007; Strauss et al., 2009a). The consensus among forest scientists has been on the contrary; that the regulatory scrutiny should be on the product and not on the process (McHughen and Smyth, 2008; Strauss et al., 2009b). More recently, USDA (2019, 2020) has revised its regulation status and has relaxed its rules on the genetically modified crops. The regulatory oversight will now be based on the product (trait) and not entirely on the genetic engineering process. Hopefully, this change in the policy would open new avenues for deregulation of forest trees in USA. Although, pest resistant poplars have been commercialized in China since 1990's (Ewald et al., 2006), only recently frost-tolerant transgenic eucalypts hybrid (Eucalyptus grandis x E. urophylla S) (Wear et al., 2014) and genetically modified loblolly pine (Pinus taeda) engineered for increased wood density (Miller et al., 2019) are undergoing the deregulation process in the United States of America, and are expected to be released in the United States of America's market in the near future.

\section{Climate change impacts on forest tree}

Global climate has been changing in the past and will continue to change in the future. What is new is that according to current estimates by meteorologists global warming has been occurring at an accelerated rate. The Intergovernmental Panel on Climate Change (IPCC) has made projections on increase of global mean temperatures by the end of the current century. The Fourth Assessment Report (AR4) by IPCC (2007) predicted 
a global temperature increase between $2.4^{\circ} \mathrm{C}$ to $6.4^{\circ} \mathrm{C}$, accompanied by significant changes in precipitation (Allan and Sodan, 2008; O'Gorman and Schneider, 2009; Trentberth, 2011), while the AR5 report by IPCC (2014) predicted a temperature rise between $2.6^{\circ} \mathrm{C}$ and $4.8^{\circ} \mathrm{C}$, depending on the locations with low or high emission of carbon dioxide $\left(\mathrm{CO}_{2}\right)$. However, a recent IPCC (2018) assessment report suggests that global warming is likely to reach $1.5^{\circ} \mathrm{C}$ between 2030 and 2052, if it continues at the current rate. These changes in global warming are likely caused by anthropogenic greenhouse gases, mainly $\mathrm{CO}_{2}$, resulting from the industrial combustion of fossil fuel in the atmosphere, and have contributed to about $78 \%$ of the total greenhouse gas emissions increase from 1970 to 2010 (IPCC 2014).

Rapid climate change may impact plant/tree species in a number of different ways, including: (1) range shifts, migration, and geographical redistribution (Aitken et al., 2008; Iverson et al., 2005, 2008; Mckenney et al., 2007; Kelly and Gouldon 2008; Thuiller et al., 2008; Iverson and McKenzie, 2013; Monleon and Lintz 2015; Takolander et al., 2019); (2) shifts in phenology (e.g. flowering time) (Franks et al., 2007; Craufurd and Wheeler, 2009; Anderson et al., 2012; Gaira et al., 2014; Prevéy et al., 2019); (3) threat to biodiversity (Botkin et al., 2007; Bellard et al., 2012; Javeline et al., 2013); (4) ecosystem disturbance and wildfires (Kirilenko and Sedjo, 2008; Littell et al., 2010; Stuadet et al., 2013; Bellard et al., 2014; Mahi et al. 2019); (5) forest growth, drought and mortality (Battles et al;. 2008; Allen et al., 2010, 2015; Quirk et al., 2013); (6) changes in genetic and evolutionary response (Davis et al., 2005; Hoffmann and Willi, 2008; Hoffmann and Sgro, 2010; Rehfeldt et al., 2014); and (7) extinction risks (Thomas et al., 2004; Pearson et al., 2014; Urban, 2015). In addition to the above mentioned impacts on plants, climate change is also presumable causing changes in the environment, including increased drought conditions, changes in precipitation, and increase in sea levels. Clonal forestry and transgenic forestry will have to cope with rapidly changing climate and global warming.

\section{Climate change mitigation and forest tree adapta- tion}

A range of technologies has to be employed for mitigating climate change and global warming. There are at several geoengineering mitigation and adaptation strategies that are currently employed to cope with $\mathrm{CO}_{2}$ and global warning (Zhang et al., 2015; Fawzy et al., 2020). One is land-based for $\mathrm{CO}_{2}$ sequestration by large scale reforestation programs (Nave et al., 2019; Domke et al., 2020). A recent study (Bastin et al., 2019) suggests that about 0.9 billion hectares of land world-wide would be suitable for reforestation, which could ultimately capture two thirds of human-made carbon emissions. Such a reforestation program would serve as a powerful tool for carbon sequestration from the atmosphere. In order to meet the $1.5^{\circ} \mathrm{C}$ target, it would be required to remove at least some of the carbon dioxide that was previously emitted. The future goal of global warming mitigation would be to achieve NetZero carbon emissions by 2050 (Matemilola and Salami, 2020). Net-Zero emissions by 2050 would require global alliances between nations for rapid and large scale reduction of greenhouse gases and other toxic elements in the atmosphere, and carbon sequestration (Fuss et al., 2020; Rogelj et al., 2021)). Second approach is atmosphere-based and involves injecting aerosols (e.g. sulfur dioxide) into the stratosphere by aircrafts for solar radiation management. The sulfur dioxide is oxidized in the atmosphere to sulfuric acid, which has a low enough vapor pressure to form cloud droplets to block solar radiation (Robock, 2014). The third approach is ocean-based, and involved ocean fertilization by adding iron (iron sulfate), urea (source of nitrogen), and phosphorus to stimulate phytoplankton growth and population. Phytoplanktons absorb $\mathrm{CO}_{2}$ through photosynthesis and form a food chain in the ocean. When phytoplanktons die, they sink taking the photosynthate with them to ocean floor, thus sequestering atmospheric $\mathrm{CO}_{2}$ (Williamson et al., 2012). The fourth approach is albedo-based that involves reflection of incoming short-wave radiation from sunlight by the leaf surface by plants and tree canopy (Davies-Barnard, 2014). The albedo affect could be overcome by growing plants/ trees with that have broad and waxy leaves/needles to deflect solar energy.

There are at least four broad options for adaptation of forest trees to rapid climate change: (1) strategies for mitigation of climate change, (2) translocation of clonal material by managed relocation (one type of assisted migration) to new locations to pursue biological diversity, ecosystem functioning as an adaptation strategy for coping with climate change, in the event that the current habitat is to become unsuitable because of climate change (Richardson et al. 2009; Schwartz et al. 2012; Locatelli et al., 2015), (3) selection of genotypes from the germplasm in the forest tree species of interest that are tolerant to environmental stresses, including drought, frost, and pests, and are amenable for in vitro clonal propagation, and (4) employment of biotechnological approaches to produce novel genotypes that are resilient and tolerant to climate change effects. I shall discuss climate change mitigation, and biotechnological approaches to cope with climate change in the following sections.

\section{Biotechnological strategies for coping with climate change}

Global climate change is impacting species distributions and functioning and their terrestrial ecosystem (Parmesan, 2006; Thuiller et al., 2008). There is substantial evidence to suggest that species ranges are shifting (Iverson and McKenzie, 2013; Monleon and Lintz 2015; Takolander et al., 2019) and some species are facing extinction risks (Thomas et al., 2004; Schwartz et al., 2006; Cahill et al., 2013; Román-Palacios and Wiens, 2020). Different models have been used to estimate plant migration patterns to potentially suitable habitats under the future climate change scenarios, and it appears that many North American species will likely shift their ranges at a rate of 10 to $100 \mathrm{~km} / 100$ years to keep pace with the predicted climate change in this century (Davis et al., 2005; Iverson and Prasad, 2005; Iverson et al., 2019). Iverson et al., (2008) have examined the potential response of 134 tree species in the USA under different climate change scenarios in this century. Depending on 
the climate change model, they predicted that more than a one-third of the tree species could shift their ranges more than $400 \mathrm{~km}$ northwards, and in the hottest climate change scenario, most of the species would advance up to $800 \mathrm{~km}$ northwards (Iverson et al., 2008).

These studies suggest that it would be necessary to devise strategies for the future survival and evolution of forest trees facing unpredictable climate change. In this direction, biotechnological approaches involving gene editing offer several options for producing transgenic trees that can adapt to climate change. These include: (1) engineering trees for improved growth rates, canopy morphology, and enhanced photosynthetic activity for improved carbon sequestration; (2) genetically engineer to produce transgenic trees that have broad and waxy leaf surface facing sunlight to reflect heat back into space, and (3) produce transgenic trees that are stress tolerance. Here I shall focus on two stress-related traits that will be important for the adaptation of forest trees to climate change. These include tolerance to drought and frost (cold) stress. Drought tolerance would be critical for forest trees for their continued adaptation and survival in their original locations affected by global warming. Frost tolerance, on the other hand, would be important for those tree species that could not adapt to global warming and had to be moved by assisted migration to colder climates for their survival.

One approach involves use of somaclonal variation in tissues of selected clones in vitro to induce epigenetic or genetic changes for stress tolerant trait. In several studies, polyethylene glycol (PEG) has been used in plant tissue cultures to induce stress tolerance in plants (Joshi et al., 2011; Montalbán et al. 2014; Mishra et al., 2021). Towards this goal, I suggest, induction of callus formation in both organogenesis and somatic embryogenesis cultures of forest tree species by using appropriate levels of PEG and/or 2,4-dichlorophenoxyacetic acid (2,4D) (Liu et al., 2013$)$, at temperature ranges $\left(25-30^{\circ} \mathrm{C}\right)$, and select for plantlets or somatic seedlings tolerant to drought and/or frost.

The second strategy calls for transfer of stress tolerant genes (drought tolerant or frost tolerant) into selected clones of a forest tree species by genetic engineering. Although both drought tolerance and frost tolerance may be controlled by a number of genes, their biosynthetic pathways are still unknown. Since drought and frost tolerance are polygenic traits, genetic transformation of a single gene appears to have limited potential on drought and frost stress tolerance. However, a number of transcription factor binding proteins related to drought and frost tolerance have been isolated and identified. These include CDPK (Calcium dependent protein kinase), DREB (dehydration responsive element binding protein), CBF (c-repeat binding factor) transcription factors for drought; and CBF1 (DRE-binding protein) and COR (cold responsive gene) for frost tolerance isolated from plant/tree species (Winiewski et al., 2014; Polle et al. 2019; Chang et al., 2021). The transgenes encoding transcription factors binding proteins activate the drought tolerance (Kudo et al., 2017; Polle et al., 2019; Schulz et al., 2021) and cold tolerance (Chinnusami et al., 2007; Wisniewski et al., 2014; Wani et al., 2016; Gao et al., 2021) inducible genes, which have been used for genetic transformation of a number of mostly annual plant species.

There are two options for stress tolerance gene transfer: (1) transfer of stress tolerant transcription factor binding protein coding gene (drought tolerance or frost tolerance), along with a pest tolerant $(B T)$ gene in a selected forest tree clone, and/or, (2) genetically engineer drought tolerance or frost tolerance transcription factor genes into a transgenic genotype that already carries a transgene for an economic trait (for example, pest resistance). As it turns out, both pest resistance and drought tolerance traits would be useful, as with increasing temperatures and humidity, insect pests population will also increase (Battisti and Larsson 2015; Sangle et al., 2015; Skendvžić et al., 2021). Test these genotypes in greenhouse with drier or colder atmospheres. Alternatively, move transgenic genotypes by managed relocation (a type of assisted migration) to pole-ward locations to test for frost-tolerance, or in drier southward locations for testing drought tolerance. It is suggested that tissues/organs from these transgenic genotypes should be stored in gene banks using cryopreservation techniques (Keller and Senula 2010; Gonzalez-Arnao et al., 2014) for future exploitation to cope with the rapid climate change.

\section{Concluding statement}

Clonal forestry by organogenesis and somatic embryogenesis has been making progress. However, there are still some limitations to the commercial deployment of clonal material. Among them are the technical problems to clonally propagate mature selected genotypes in vitro, and costs of propagule production. These problems may be addressed by innovative techniques in biotechnology for cost-effective production of forest tree clones by in vitro. Clonal forestry and transgenic forestry will have to cope with rapid climate change. $\mathrm{CO}_{2}$ sequestration by large-scale reforestation programs (Boyd 2010), and geoengineering (Zhang et al., 2015) offers prospects for combating climate change. Managed relocation offers opportunities to test the capacity of the forest clonal material to adapt to the new environment in the new locations in the face of climate change. Biotechnological approaches using somaclonal variation and genetic engineering would be necessary to produce clonal transgenic materials that are tolerant to climate change stresses.

\section{References}

Ahuja MR (1983) Somatic cell differentiation and rapid clonal propagation of aspen. Silvae Genet 32:131-135

Ahuja MR (1984) A commercially feasible micropropagation method for aspen. Silvae Genet 33:174-176

Ahuja MR (1986) Aspen. In: Evans DE, Sharp WR, Ammarito PJ (eds) Hanbook of plant cell culture, McMillan Publishing Company, New York, pp 626-651

Ahuja MR (1987a) In vitro propagation of poplar and aspen. In: Bonga JM, Durzan DJ (eds) Cell and tissue culture in forestry. Vol. 3. Martinus Nijhoff

Publishers, Dordrecht, pp 207-223

https://doi.org/10.1007/978-94-017-0992-7 16 
Ahuja MR (1987b) Somaclonal variation. In: Bonga JM, Durzan DJ (eds) Cell and tissue culture in forestry. Vol 1. Martinus Nijhoff Publishers, Dordrecht, pp 272-285. https://doi.org/10.1007/978-94-017-0994-1_16

Ahuja MR (1988a) Somatic cell genetics of woody plants. Kluwer Academic Publishers, Dordrecht

Ahuja MR (1988b) Gene transfer in forest trees. In: Hanover JE, Keathley DE (eds) Genetic Manipulation of Woody Plants. Plenum Press, New York, pp. 25-41. https://doi.org/10.1007/978-1-4613-1661-9_2

Ahuja MR (1991) Woody plant biotechnology. Plenum Press, New York https://doi.org/10.1007/978-1-4684-7932-4_1

Ahuja MR (1993a) Micropropagation of woody plants. Kluwer Academic Publishers, Dordrecht

Ahuja MR (1993b) Regeneration and germplasm preservation in aspen-Populus. In: Ahuja MR (ed) Micropropgation of woody plants. Kluwer Academic Publishers, Dordrecht, pp 187-194 https://doi.org/10.1007/978-94-015-8116-5 11

Ahuja MR (1996) Micropropagation and field testing of frost-tolerant Sequoic sempervirens genotypes. In: LeBlanc J (ed) Proceeding of the conference on coast redwood forest ecology and management. Humboldt State University, Arcata, pp 153-155

Ahuja MR (1997) Transgenes and genetic instability. In: Klopfenstein NB, Chun WYW, Kim MS, Ahuja MR (eds) Micropropagation and genetic engineering and molecular genetics of Populus. Tech. Rep. RM-GTR-297, USDA Forest Service, Rocky Mountain Research Station, Fort Collins, pp 90-100

Ahuja MR (1998) Somaclonal genetics of forest trees. In: Jain SM, Brar DS, Ahloowalia BS (eds) Somaclonal variation and induced mutations in crop improvement. Kluwer Academic Publishers, Dordrecht, pp 105-121 https://doi.org/10.1007/978-94-015-9125-6_6

Ahuja MR (2000) Genetic engineering in forest trees: state of the art and future perspectives. In: Jain SM, Minocha SC (eds) Molecular biology of woody plants. Vol 1. Kluwer Academic Publishers, Dordrecht, pp 31-49 https://doi.org/10.1007/978-94-017-2311-4_2

Ahuja MR (2001) Recent advances in molecular genetics of forest trees. Euphytica 121: 73-195

Ahuja MR (2005) Polyploidy in gymnosperms: Revisited. Silvae Genet 54:59-69 https://doi.org/10.1515/sg-2005-0010

Ahuja MR (2009a) Genetic constitution and diversity in four narrow endemic redwoods from the family Cupressaceae. Euphytica 165:5-19 https://doi.org/10.1007/s10681-008-9813-3

Ahuja MR (2009 b). Transgene stability and dispersal in forest trees. Trees 23: 1125-1135. https://doi.org/10.1007/s00468-009-0362-8

Ahuja MR (2011a) Strategies for conservation of germplasm in endemic redwoods in the face on climate change: a review. Plant Genetic Resources 9:411-422. https://doi.org/10.1017/s1479262111000153

Ahuja MR (2011 b) Fate of transgenes in the forest tree genome. Tree Genetics \& Genomes 7: 221-230. https://doi.org/10.1007/s11295-010-0339-1

Ahuja MR (2014a) Regulation of transgene expression and containment in forest trees. In: Ramawat KG, Merillon JM, Ahuja MR (eds) Tree Biotechnology. CRC Press, Boca Raton, pp337-365

Ahuja MR (2014b) Next generation plant biotechnology. In: Ahuja MR, Ramawat KG (eds) Biotechnology and biodiversity. Springer International Publishing, Switzerland, pp 77-100. https://doi.org/10.1007/978-3-319-09381-9 6

Ahuja MR (2017) Climate change, genetic diversity, and conservation of paleoendemic redwoods. In: Ahuja MR, Jain SM (eds) Biodiversity and conservation of woody plants. Springer Verlag, Switzerland, pp 69-93 https://doi.org/10.1007/978-3-319-66426-2_3

Ahuja MR, Fladung M (1996) Stability and expression of chimeric genes in Populus. In: Ahuja MR, Boerjan W, Neale DB (eds.) Somatic cell genetics and molecular genetics of trees. Kluwer Academic Publishers, Dordrecht, pp 8996. https://doi.org/10.1007/978-94-011-3983-0_12

Ahuja MR, Fladung M (2014) Integration and inheritance of transgenes in crop plants and trees. Tree Genetics \& Genomes 10:779-790 https://doi.org/10.1007/s11295-014-0724-2

Ahuja MR, Libby WJ (1993a) Clonal forestry I. Genetics and biotechnology. Springer Verlag, Berlin. https://doi.org/10.1007/978-3-642-84175-0

Ahuja MR, Libby WJ (1993b) Clonal forestry II. Conservation and application. Springer Verlag, Berlin. https://doi.org/10.1007/978-3-642-84813-1
Ahuja MR, Muhs HJ (1985) In vitro techniques in clonal propagation of forest trees. In: Schaefer-Menuhr (ed) In vitro techniques propagation and long-term storage. Martinus Nijhoff/Dr W. Junk Publishers, Dordrecht, pp. 41-49

Ahuja MR, Neale DB (2002) Origins of polyploidy in coast redwood (Sequoia sempervirens (D.Don) Endl.) and relationship of coast redwood to other genera of Taxodiaceae. Silvae Genet 51: 93-100

Abaimov AP (2010) Geographical distribution and genetics of Siberian larch species. In: Osawa A, Zyryanova OA, Matsuura Y, Kajimoto T, Wein RW (eds) Permafrost ecosystems - Siberian larch forests, Springer Verlag, Berlin, pp. 41-58. https://doi.org/10.1007/978-1-4020-9693-8_3 3

Aitkin SN, Yeaman S, Holiday JA, Wang T, Curtis-McLane S (2008) Adaptation, migration or extirpation: climate change outcomes of tree populations. Evolutionary Applications 1:95-111 https://doi.org/10.1111/j.1752-4571.2007.00013.x

Allan RP, Soden BJ (2008) Atmospheric warming and the amplification of precipitation extremes. Science 321:1481-1494 https://doi.org/10.1126/science.1160787

Allen CD, Breshears DD, McDowell (2015) On underestimating of global vulnerability to tree mortality and forest die-off from hotter drought in the anthropocene. Ecosphere 6:129. https://doi.org/10.1890/es15-00203.1

Anderson JT, Inouye DW, McKinney AM, Colauti RI, Mitchell-Olds T (2012) Phenotypic plasticity and adaptive evolution contribute to advancing flowering phenology in response to climate change. Proc R Soc B 279:3843-3852 https://doi.org/10.1098/rspb.2012.1051

Arnaud Y, Franclet A, Tranvan H, Jacques M (1993) Micropropagation and rejuvenation of Sequoia sempervirens (Lamb) Endl.): A review. Annales des Sciences Forestieres 50:273-295. https://doi.org/10.1051/forest:19930305

Arno SF, Habeck JR (1972) Ecology of Alpim=ne larch (Larix lyallii) in the Pacific Northwest. Ecological Monograph 42:417-450 https://doi.org/10.2307/1942166

Bairu MW, Aremu AO, van Staden J (2011) Somaclonal variation in plants: causes and detection methods. Plant Growth Regul 63:147-173 https://doi.org/10.1007/s10725-010-9554-x

Ball EA (1950) Differentiation in a callus culture of Sequoia sempervirens. Growth 14: $295-325$

Ball EA, Morris DM, Reydelius JA (1978) Cloning of Sequoia sempervirens from mature trees through tissue culture. Round Table Conference. In Vitro Multiplication of Woody Species, Gamboloux, Belgium, pp.181-226

Bastin J-F, Finegold Y, Garcia C, Mollicone D, Rezende M, Routh D, Zohner CM, Crowther TW (2019) The global tree restoration potential, Science 365:76-79 https://doi.org/10.1126/science.aax 0848

Battisti A, Larsson S (2015) Climate change and insect pest distribution range. In: Björkman C, Niemelä (eds) Climate change and insect pests, CAB International, pp 1-15. https://doi.org/10.1079/9781780643786.0001

Battles JJ, Robards T, Das A, Waring K, Gilless JK, Biging G, Schurr F (2008) Climate change impacts on forest growth and tree mortality: a data-driven modeling study in the mixed-conifer forest of Sierra Nevada, California. Climatic Change 87 (Supplement 1):S193-S213 https://doi.org/10.1007/s10584-007-9358-9

Bellard C, Bertelsmeier C, Leadley P, Thuiller W, Courchamp F (2012) Impacts of climate change on the future of biodiversity. Ecol Lett 15:365-377 https://doi.org/10.1111/j.1461-0248.2011.01736.x

Bellard C, Leclerc C, Leroy B, Bakkenes M, Veloz S, Thuiller W, Courchamp F (2014) Vulnerability of biodiversity hotspots to global change. Global Ecol Biogeogr 23:1376-1386. https://doi.org/10.1111/geb.12228

Bello-Bello J, Iglesioas-Andreu L, Sanchez-Velasquez L, Casas-Martinez J, Santana-Buzzy N (2012) In vitro regeneration of Pinus brutia Ten. Var. eldarica (Medw.) through organogenesis. African J Biotech 11:15982-15987 https://doi.org/10.5897/ajb12.2180

Bock R (2006) Plastid biotechnology: prospects for herbicide and insect resistance, metabolic engineering and molecular farming. Curr Opinion Biotech 17: $1-7$

Boerjan W (2005) Biotechnology and domestication of forest trees. Curr Opinion Biotech 16: 159-166. https://doi.org/10.1016/j.copbio.2005.03.003

Bon MC, Riccari F, Monteuuis O (1994) Influence of phase change within a 90year old Sequoia sempervirens on its in vitro organogenic capacity and protein patterns. Trees 8:283-287. https://doi.org/10.1007/bf00202672

Bonga JM (2012) Recalcitrance in the in vitro propagation in conifers. In: Park YS, Bonga JM (eds) Proc IUFRO WP 2.09.02 conference on Integrating veg- 
etative propagation, biotechnology and genetic improvement for tree production and sustainable forest management. Brno Czech Republic, pp 37-46

Bonga JM (2016) Conifer clonal propagation in tree improvement programs. In: Park YS, Bonga JM, Moon HK (eds) Vegetative propagation of forest trees. National Institute of Forest Science (NIFoS) Korea, pp 3-31

Bonga JM, Durzan DJ (1987) Cell and tissue culture in forestry. Vol. 3. Martinus Nijhoff Publishers, Dordrecht. https://doi.org/10.1007/978-94-009-4484-8

Bonga JM, Klimaszewska KK, von Aderkas P (2010) Recalcitrance in clonal propagation, in particular of conifers. Plant Cell Tiss Organ Cult 100:241-254 https://doi.org/10.1007/s11240-009-9647-2

Bonga JM, Parks YS, Trontin JF (2018) Proceedings of the 5th international conference of the IUFRO Unit 2,09.02 on "Clonal Trees in the bioeconomy age: opportunities and challenges." September 10-15, 2018. Coimbra, Portugal

Botkin DB, Saxe H, Arauju MB, Betts R, Bradshaw RHW, Cedhagen T, Chesson P, Dawson TP, Etterson JR, Faith DP, Ferrier S, Guisan A, Hansen AS, Hilbert DW Loehle C, Margules, C, New M, Sobel MJ, Stockwell DRB (2007) Forecasting the effects of global warming on biodiversity. Bioscience 57:227-236 https://doi.org/10.1641/b570306

Boulay M (1978) Multiplication rapide du Sequoia sempervirens en culture in vitro. Annales AFOCEL, pp 37-66

Boyd E (2010) Societal choice for climate change futures: trees, biotechnology and clean development. Bioscience 60:743-750 https://doi.org/10.1525/bio.2010.60.9.11

Bradford KJ, Deynze AV, Gutterson N, Parrott W, Strauss SH (2005) Regulating transgenic crops sensibly: lessons from plant breeding, biotechnology and genomics. Nature Biotech 23: 439-444. https://doi.org/10.1038/nbt1084

Briones MV, Hoenicka H, Canñs, LA, Beltrán, JP, Hanelt D, Sharry S, Fladung M (2020) Efficient evaluation of gene containment system for poplar through early flowering induction. Plant cell Rep 39:577-587 https://doi.org/10.1007/s00299-020-02515-1

Breton D, Harvengt L, Trontin JF, Bouvet A, Favre JM (2006) Long-term subculture randomly affects morphology and subsequent maturation of early somatic embryos in maritime pine. Plant Cell Tiss Organ Cult 87:95-108 https://doi.org/10.1007/s11240-006-9144-9

Bruegmann T, Wetzel H, Hettrich K, Smeds A, Willför S, Kersten B, Fladung M (2019a) Knockdown of PCBERI 1, a gene of neolignin biosynthesis results in increased poplar growth. Planta 249:515-525 https://doi.org/10.1007/s00425-018-3021-8

Bruegmann T, Deecke K, Fladung M (2019b) Evaluating the efficiency of gRNAs in CRISPR/Cas9 mediated genome editing in poplars. Int J Mol Sci 20:3623 https://doi.org/10.3390/ijms20153623

Brunner AM, Li J, DiFazio SP, Schevchenko O, Montgomery BE, Mohamed R, Wei H, Ma C, Elias AN, Van Wormer K, Strauss SH (2007) Genetic containment of forest plantations. Tree Genetics \& Genomes 3: 75-100 https://doi.org/10.1007/s11295-006-0067-8

Butaye KMJ, Cammue BPA, Delauré SL, De Bolle MFC (2005) Approaches to minimize variation in transgene expression in plants. Mol Breed 16:79-91 https://doi.org/10.1007/s11032-005-4929-9

Cahill A, Aiello-Lammens E, Fisher-Reid MS, Hua X, Karanewsky CJ, Ryu HY, Sbeg lia GC, Spagnolo F, Waldron JB, Warsi O, Wiens JJ (2013) How does climate change cause extinction? Proc R Soc B 280:20121890 https://doi.org/10.1098/rspb.2012.1890

Chalupa V (1985) Somatic embryogenesis and plantlet regeneration from cultured immature and mature embryos of Picea abies (L.) Karst. Comm Inst For Zech Republic 14:57-63

Chang S, Mahon EL, McKay HA, Rottman WH, Strauss SH, Pijut PM, Powell WA, Coffey V, Lu H, Mansfield SD, Jones TJ (2018) Genetic engineering of trees: progress and new horizons. In Vitro Cell Develop Biol-Plant 54:341-376 https://doi.org/10.1007/s11627-018-9914-1

Chang CY-Y, Bräutigam K, Hüner NPA, Ensminger I (2021) Champions of winter survival: cold acclimation and molecular regulation of cold hardiness in evergreen conifers, New Phytologist 229:675-691 https://doi.org/10.1111/nph.16904

Charest PJ, Michel MF (1991) Basics of plant genetic engineering and potential application to tree species. Information Report PI-X-104. Petawawa National Forestry Institute, Forestry Canada, pp 1-48

Charity JA, Holland L, Grace LJ, Walter C (2005) Consistent and stable expression of the $n p t \mathrm{II}$, uidA and bar genes in transgenic Pinus radiate after Agro- bacterium tumefaciens-mediated transformation using nurse cultures. Plant Cell Rep 23:606-616. https://doi.org/10.1007/s00299-004-0851-6

Chinnusamy V, Zhu J, Zhu J-K (2007) Cold stress regulation of gene expression in plants. Trends in Plant Science 12 https://doi.org/10.1016/j.tplants.2007.07.002

Coleman GD, Ernst SG (1989) In vitro shoot regeneration of Populus deltoids: effect of cytokinin and genotype. Plant Cell Rep 8:459-462 https://doi.org/10.1007/bf00269048

Coritzo M, de Diego N, Moncaleán P, Ordás RJ (2009) Micropropgation of adult stone pine (Pinus pinea L.). Trees 23:835-842 https://doi.org/10.1007/s00468-009-0325-0

Craufurd PQ, and Wheeler TR (2009) Climate change and flowering time in annual crops. J. Exptl Bot 60:2529-2539. https://doi.org/10.1093/jxb/erp196

Custers R, Bartsch D, Fladung M, Nilsson O, Pilate G, Sweet J, Boerjan W (2016) EU regulations impede market introduction of GM forest trees. Trends Plant Sci 21:283-285. https://doi.org/10.1016/j.tplants.2016.01.015

Davies-Barnard T (2014) Cooling the Earth with crops. In: Hester RE, Harrison RM (eds) Geoengineering of the climate change. Royal Society of Chemistry Publishers, pp 105-130

Davis MB, Shaw RG, Etterson JR (2005) Evolutionary responses to climate change. Ecology 86:1704-1704. https://doi.org/10.1890/03-0788

De Oliveira LF, Ribas LLF, Quoirin M, Koehler HS, Amano E, Higa AR (2012) Micropropagation of Pinus taeda L. from juvenile material. Tree Forestry Science Biotech 6:96-101

DeRose RJ, Mock KE, Long JN (2015) Cytotype differences in radial increment provide novel insight into aspen reproductive ecology and stand dynamics. Can J For Res 45:1-8. https://doi.org/10.1139/cjfr-2014-0382

DeWoody J, Rowe CA, Hipkins VD, Mock KE (2008) “Pando" lives: molecular genetic evidence of a giant aspen clone in central Utah. Western North American Naturalist 68:493-497. https://doi.org/10.3398/1527-0904-68.4.493

Domke GM, Oswalt SN, Walters BF, Morin RS (2020) Tree planting has the potential to increase carbon sequestration capacity of forests in the United States. Proc Natl Acad Sci (USA) 117:24649-24651 https://doi.org/10.1073/pnas.2010840117

Ellstrand NC (2018) "Born to run"? Not necessarily: species and trait bias in persistent free-living transgene plants. Front Bioeng Biotechnol 6:88 https://doi.org/10.3389/fbioe.2018.00088

Eriksson G, Ekberg I, Clapham D (2013) Genetics applied to forestry, $3^{\text {rd }}$ Edition. Elanders Sverige Printing, Sweden

Erst AA, Bakulin VT, Erst AS, Kuznetzov A, Zhumanovich E (2014) In vitro propagation of ornamental hybrids of Populus L. Bioscience Biotech Res Asia 11:69-77. https://doi.org/10.13005/bbra/1442

Ewald D (2007) Micropropagation of yew (Taxus baccata L.). In: Jain SM, Häggman $\mathrm{H}$ (eds) Protocols for micropropagation of woody trees and fruits. Springer Verlag, Berlin, pp 117-123 https://doi.org/10.1007/978-1-4020-6352-7 11

Ewald D, Hu, J, Yang M (2006) Transgenic forest trees in China. In: Faldung M, Ewald D (eds) Tree transgenesis: recent developments. Springer Verlag, Berlin, pp. 25-45. https://doi.org/10.1007/3-540-32199-3_2

Fan D, Liu T, Li C, Jiao B, Li S, Hou Y, Luo K (2015) Efficient CRISPR/Cas9-mediated targeted mutagenesis in Populus in the first generation. Scientific Reports 5:12217. https://doi.org/10.1038/srep12217

Farnum P, Lucier A, Meilan R (2007) Ecological and population genetics research imperatives for transgenic trees. Tree Genetics and Genomes 3: 119-133 https://doi.org/10.1007/s11295-006-0063-z

Fawzy S, Osman Al, Doran J, Rooney DW (2020) Strategies for mitigation of climate change- a review. Environmental Chemistry Letters 18:2069-2094 https://doi.org/10.1007/s10311-020-01059-w

Fillatti JJ, Selmer J, McCown B, Haissig B, Comai L (1987) Agrobacterium mediated transformation and regeneration of Populus. Mol Gen Genet 206:192199. https://doi.org/10.1007/bf00333574

Finnegan J, McElroy d (1994) Transgene inactivation: plants fight back. Biotechnology 12:883-888. https://doi.org/10.1038/nbt0994-883

Finstad K, Bonfils AC, Shearer W, Macdonald P (2007) Trees with novel traits in Canada: regulation and related scientific issues. Tree Genetics \& Genomes 3:135-139. https://doi.org/10.1007/s11295-006-0080-y

Fladung M (1990) Transformation of diploid and tetraploid potato clones with the rolC gene of Agrobactrium rhizogenes and characterization of trans- 
genic plants. Plant Breeding 104:295-304. https://doi.org/10.1111/j.1439-0523.1990.tb00439.x

Fladung M. Becker D (2010) Targeted integration and removal of transgenes in hybrid aspen (Populus tremula L. x P. tremuloides Michx.) using site-specific recombination system. Plant Biol 334-340

Fladung M, Bullovra A (1992) Further characterization of rolC transgenic tetraploid potato clones, and influence of daylength and level of rolC expression on yield parameters. Plant Breeding 109:18-27 https://doi.org/10.1111/j.1439-0523.1992.tb00145.x

Fladung M, Hoenicka H (2012) Fifteen years of forest tree biosafety research in Germany. IForest 5:126-130. https://doi.org/10.3832/ifor0619-005

Fladung M, Hoenicka H, Ahuja MR (2013) Genomic stability and long-term transgene expression in poplars. Transgenic Res 22:1167-1178 https://doi.org/10.1007/s11248-013-9719-2

Fladung M, Kaldorf M, Gieffers W, Ziegenhagen B, Muhs HJ, Kumar S (2004) Field analysis of transgenic aspen. In: Walter C, Carson M (eds) Plantation forest biotechnology for the $21^{\text {st }}$ century, Kerala, pp 393-403

Fladung M, Kumar S, Ahuja MR (1997) Genetic transformation of Populus genotypes with different chimeric gene constructs: transformation efficiency and molecular analysis. Transgenic Res. 6: 111-121

Fladung M, Kumar S (2002) Gene stability in transgenic aspen-Populus. III. T-DNA repeats influence transgene expression differentially among different transgenic lines. Plant Biol 4:329-338.https://doi.org/10.1055/s-2002-32329

Fladung M, Muhs H, Ahuja MR (1996) Morphological changes in transgenic Populus carrying the rolC gene from Adrobacterium rhizogenes. Silvae Genet 45 349-354

Fladung M, Nowitzki O, Kumar S. Hoenicka H (2005) The site-specific recombination systems Cre-lox and FLP-FRT are functionally active in poplar. Forest Genetics 12:121-130

Fladung M, Schenk, TMH, Polak O, Becker D (2010) Elimination of marker genes and targeted integration via FLP/FRT recombination system from yeast in hybrid aspen (Populus tremula L. x P. tremuloides Michx.). Tree Genetics \& Genomes 6:205-217. https://doi.org/10.1007/s11295-009-0241-x

Franks SJ, Sim S, Weis AE (2007) Rapid evolution of flowering time by an annua plant in response to a climate fluctuation. Proc Natl Acad Sci USA 104:12781282. https://doi.org/10.1073/pnas.0608379104

Fry JH, Douglas GC, Saieed NT (1997) Somaclonal variation in Populus: an evaluation. In: Klopfenstein NB, Chun WYW, Kim MS, Ahuja MR (eds) Micropropagation and genetic engineering and molecular genetics of Populus. Tech. Rep. RM-GTR-297, USDA Forest Service, Rocky Mountain Research Station, Fort Collins, pp 33-43

Fuss S, Candell J, Ciais P et al (2000) Moving towards net-zero emissions requires new alliance for carbon dioxide remonal. One Earth 3:145-149 https://doi.org/10.1016/j.oneear.2020.08.002

Gaira KS, Rawal, RS, Rawat, B, Bhatt ID (2014) Impact of climate change on the flowering of Rhododendron arboretum in central Himalaya, India. Current Science 106:1735-1738

Gamburg KZ, Voinikov VK (2013) Somaclonal variations as a mean for obtaining regenerants with different growth rates in poplar (Populus $\mathrm{x}$ berolinensis Dipp.). Natural Sciences 5:599-607. https://doi.org/10.4236/ns.2013.55075

Gao W, Bai S, Gao C, Liu G, Li G, Tan F (2013) Overexpression of TaLEA gene from Tamrix androssowii improves salt and drought tolerance in transgenic poplar (Populus simonii x P. nigra). PLoS ONE 8:e67462 https://doi.org/10.1371/journal.pone.0067462

Gao J, Dou T, He W, Shen O, Bi F, Deng G, Gao H, Dong T, Li C, Zhang S, Yi G, Hu C, Yang Q (2021) MaMAPK3-MAICE1-MAPOD P7 pathway, a positive regulator of cold tolerance in banana. BMC Plat Biology 21:97 https://doi.org/10.1186/s12870-021-02868-z

Gautheret RJ (1934) Culture du tissue cambial. VR Acad Sci (Paris) 198:2195-2196

Gautheret RJ (1940) Recherches sur le bourgeonnement du tissue cambial d'UImus campestris, cultitive in vitro. CR Acad Sci (Paris) 210:632-634

Gidoni D, Srivastava V, Carmi M (2008) Site-specific excision-recombination strategies for elimination of undesirable transgenes from crop plants. In Vitro Cell Dev. Biol. Plant 44: 457-467 https://doi.org/10.1007/s11627-008-9140-3

Gonzalez-Arnao MT, Martinez-Montero ME, Cruz-Croz CA, Engelmann F (2014) Advances in cryogenic techniques for the long-term preservation of plant biodiversity. In: Ahuja MR, Ramawat GK (eds) Biotechnology and biodiversity,
Springer International Publishing, Swtizerland, pp 129-170

https://doi.org/10.1007/978-3-319-09381-9_8

Grant MC (1993) The trembling giant. Discover (October):83-88

Grant MC, Mitton JB, Linhart YB (1992) Even larger oraganisms. Nature 360: 216. https://doi.org/10.1038/360216a0

Guan Y, Li SG, Fan XF, SU ZH (2016) Application of somatic embryogenesis in woody plants. Front Plant Sci 7:938. https://doi.org/10.3389/fpls.2016.00938

Gupta PK, Durzan DJ (1987) Micropropagation and phase specificity in mature elite Douglas fir. J. Amer Soc Hort Sci 112:969-971

Haberlandt G (1902) Kulturversuche mit isolierten Pflanzenzellen. Sitzungber Akad Wiss Wien Math Naturwiss K1 Abt J 111:69-92

Häggman H, Raybould A, Borem A, Fox T, Handley L, Hertzberg M, Lu MZ, Macdonald P, Oguchi T, Pasquali G, Pearson L, Peter G, Quemada H, Séguin A, Tattersall K, Ulian E, Walter C, McLean M (2013) Genetically engineered trees for plantation forests: key considerations for environmental risk assessment. Plant Biotech J 11:785-798. https://doi.org/10.1111/pbi.12100

Hakman I, Fowke LC, von Aernold S, Eriksson T (1985) The development of somatic embryos in tissue culture initiated from immature embryos of Picea $a b-$ ies (Norway spruce). Plant Sci 38:53-59 https://doi.org/10.1016/0168-9452(85)90079-2

Hawkins S, Leplé JC, Cornu D, Jouanin L, Pilate G (2003) Stability of transgene expression in poplar: a model forest tree species. Ann. For. Sci. 60:.427-438 https://doi.org/10.1051/forest:2003035

Hoffmann AA, Willi Y (2008) Detecting genetic response to environmental change. Nature Reviews Genetics 9:421-432. https://doi.org/10.1038/nrg2339

Hoffmann AA, Sgro CM (2011) Climat change and evolutionary adaptation. Nature 470:479-485. https://doi.org/10.1038/nature09670

Hoenicka H, Fladung M (2006a) Genomic instability in woody plants derived from genetic engineering. In: Fladung M, Ewald D (eds) Transgenesis: recent developments. Springer Verlag, Berlin, pp. 301-321 https://doi.org/10.1007/3-540-32199-3_14

Hoenicka H, Fladung (2006b) Faster evaluation of sterility strategies in transgenic early flowering poplar. Silvae Genetica 55:285-291 https://doi.org/10.1515/sg-2006-0037

Hoenicka h, Lautner A, Koch G (2012a) Influence of of over-expression of the FLOWERING PROMOTING FACTOR 1 gene ( $F P F 1)$ from Arabidopsis on wood formation in hybrid poplar (Populus tremula L. x P. tremuloides Michx.). Planta 235:359-373. https://doi.org/10.1007/s00425-011-1507-8

Hoenicka H, Lehnhardt D, Polak O, Fladung M (2012b) Early flowering and genetic containment studies in transgenic poplar. iForest 5:138-146 https://doi.org/10.3832/ifor0621-005

IPCC (2007) Climate change 2007. The physical science basis. Summary for policymakers. www.ipcc.ch

IPCC (2014) Climate change 2014: Impacts, adaptation, and vulnerability. Summary for policymakers. www.ipcc.ch

IPCC (2018) Global warming of 1.5 oC. In: Masson-Delmotte V, Zhai P, Pörtner $\mathrm{HO}$, et al. (eds), An IPCC special report on the impacts of global warming of 1.5 oC above pre-industrial levels and related global greenhouse emission pathways, in the context of strengthening the global response to the threat of climate change, sustainable development, and efforts to eradicate poverty. http://www.ipcc.ch

Iverson LR, Prasad AM, Schwartz MW (2005) Predicting potential changes in suitable habitat and distribution by 2100 for tree species in the eastern United States. J Agric Meteorol 61:29-37. https://doi.org/10.2480/agrmet.61.29

Iverson LR, Prasad AM, Matthews SN, Peters M (2008) Estimating potential habitat for 134 eastern US tree species under six climate scenarios. For Ecol Manage 254:390-406. https://doi.org/10.1016/j.foreco.2007.07.023

Iverson LR, McKenzie D (2013) Tree-species range shifts in the changing climate: detecting, modeling, assisting. Landscape Ecology 28:879-889 https://doi.org/10.1007/s10980-013-9885-x

Iverson LR, Peters MP, Prasad AM, Matthews SN (2019) Analysis of climate change impacts on tree species of the eastern US: results of DISTRIB-II modeling. Forests 10 https://doi.org/10.3390/f10040302

Jain SM, Gupta P (2005) Protocols for somatic embryogenesis of woody plants. Springer Verlag, Dordrecht. https://doi.org/10.1007/1-4020-2985-3

Javeline D, Hellmann JJ, Cornejo RC, Shufeldt G (2013) Expert opinion on climate change and threats to biodiversity. 63:666-673 https://doi.org/10.1525/bio.2013.63.8.9 
Joshi R, Shukla A, Sairam RK (2011) In vitro screening of rice genotypes for drought tolerance using polyethylene glycol. Aca Physiol Plant 33:22092217. https://doi.org/10.1007/s11738-011-0760-6

Kelly AE, Goulden ML (2007) Rapid shifts in plant distribution with recent climate change. Proc Natl Acad Sci USA 105: 11823-11826 https://doi.org/10.1073/pnas.0802891105

Keller ER, Senula A (2010) Cryopreservation of plant germplasm. In: Davey MR, Anthony P (eds) Plant cell culture, Wiley Blackwell Publishers, UK, pp 131-151Kirilenko AP, Sedjo RA (2007) Climate change and impacts on forestry. Proc Natl Acad Sci (USA) 104:19697-19702

Klápště J, Meason D, Dungey H, Telfer RJ, Silcok P, Rapley S (2020) Genotype-by-environment interaction in coast redwood outside natural distribution - search for environmental cues. BMC Genetics 21:15 https://doi.org/10.1186/s12863-020-0821-1

Klimaszeswka K, Trontin JF, Becwar MR, Devillard C, Park YS, Lelu-Walter MA (2007) Recent progress in somatic embryogenesis of four Pinus spp. Tree For Sci Biotech 1:11-25

Klocko AL, Brunner AM, Huang J, Meilan R, Lu H, Ma C, Morel A, Zhao D, Ault K, Dow M, Howe G, Shevchenko O, Strauss SH (2016) Containment of transgenic trees by suppression of LEAFY. Nature Biotechnology 34:918-922 https://doi.org/10.1038/nbt.3636

Klocko AL, Lu H, Magnuson A, Brunner AM, Ma C, Strauss RH (2018) Phenotypic expression and stability in a large-scale field study of genetically engineered poplars containing sexual containment transgenes. Front Bioeng Biotechnol 6:100. https://doi.org/10.3389/fbioe.2018.00100

Koch GW, Sillett CS, Jennings GM, Davis SD (2004) The limits to tree height. Nature 428:851-854. https://doi.org/10.1038/nature02417

Korban SS, Sul IW (2007) Micropropagation of coast redwood (Sequoia sempervirens) In: Jain SM, Häggman (eds) Protocols for micropropagation of woody trees and fruits. Springer Verlag, Berlin, pp 23-32 https://doi.org/10.1007/978-1-4020-6352-7 3

Krishna H, Alizadeh M, Singh D, Singh U, Chauhan N, Eftekhari M, Sadh RK (2016) Somaclonal variations and their applications in horticultural crops improvement. 3 Biotech 6:54. https://doi.org/10.1007/s13205-016-0389-7

Kruse S, Kolmogorov Al, Pestryakova LA, Herzschuh U (2020) Long-lived larch clones may conserve adaptations that could restrict treeline migration in northern Siberia. Ecololgy and Evolution 10:10017-10030 https://doi.org/10.1002/ece3.6660

Kullman L (2008) Early postglacial appearance of tree species in northern Scandinavia: review and perspectives. Quaternary Science Reviews 27:24672472 . https://doi.org/10.1016/j.quascirev.2008.09.004

Kumar S. Fladung M (2002) Transgene integration in aspen: structures of integration sites and mechanisms of T-DNA integration. Plant J 31: 543-551 https://doi.org/10.1046/j.1365-313x.2002.01368.x

Kuser J E, Bailly A, Franclet A, Libby WJ et al (1995) Early results of a range-wide provenance test of Sequoia sempervirens. Forest Genetics Resources, FAO, Rome, No. 23:21-25

Lachance D, Hamel LP, Pelltier E, Valéro J, Bernier-Cardou M, Chapman K, K Van Frankenhuyzen K, Séguin A (2007) Expression of a Bacillus thuringiensis cry$1 \mathrm{Ab}$ gene in transgenic white spruce and its efficacy against the spruce budworm (Choristoneura fumiferana). Tree Genetics \& Genomes 3: 53-167 https://doi.org/10.1007/s11295-006-0072-y

Ladics GS, Bartholomaeus A, Bregitzer P, Doerrer NG, Gray A, Holzhauser T, Jordan M, Keese P, Kok E, Macdonald P, Parrott W, Privalle L, Raybound A, Rhee SY, Rice E, Romeis J, Vaughn J, Wal J-M, Glenn K (2015) Genetic basis and detection of unintended effects in genetically modified crop plants. Transgenic Res 24:587-603. https://doi.org/10.1007/s11248-015-9867-7

Larkin PJ, Scowcroft WR (1981) Somaclonal variation - a novel source of variability from cell cultures for plant improvement. Theor Appl Genet 60: 197-214 https://doi.org/10.1007/bf02342540

Lee H, Moon HK, Park SY (2014) Agrobacterium-mediated transformation via somatic embryogenesis system in Korean fir (Abies koreana Will.), a native Korean conifer. Korean J Plant Res 27:242-248 https://doi.org/10.7732/kjpr.2014.27.3.242

Leva AR, Petruccelli R, Rinaldi LMR (2012) Somaclonal variation in tissue culture: a case study with olive. In: Leva A, Rinaldi LMR (eds) Recent advances in plant in vitro culture, InTech Publishers, pp 123-150 https://doi.org/10.5772/50367
Li J, Meilan R, Ma C, Barish M, Strauss SH (2008) Stability of herbicide resistance over eight years of coppice field-grown, genetically engineered poplars. Western J Appl For 23: 89-93. https://doi.org/10.1093/wjaf/23.2.89

Li JF, Zhang D, Sheen J (2015) Targeted genome editing via the CRISPR-Cas9 technology. In: Alonso JM, Stepanova (eds) Plant functional genomics: methods and protocols. Springer Verlag, New York, pp 239-255 https://doi.org/10.1007/978-1-4939-2444-8 12

Littell JS, Oneil EE, McKenzie D, Hicke JA, Lutz JA, Norheim RA, Elsner MM (2010) Forest ecosystems, disturbance, and climate change in Washington State, USA. Climate Change 102:129-158 https://doi.org/10.1007/s10584-010-9858-x

Liu C, Xia X, Yin W, Huang L, Zhou J (2006) Shoot regeneration and somatic embryogenesis from needles of redwood (Sequoia sempervirens (D. Don) Endl.). Plant Cell Rep 25:621-628. https://doi.org/10.1007/s00299-006-0120-y

Liu J, Yang Z, Li W, Yu J, Huang B (2013) Improving cold tolerance through in vitro selection for somaclonal variations in seashore paspalum. J Amer Soc Hort Sci 138:452-460. https://doi.org/10.21273/jashs.138.6.452

Liu Y, Yu X, Liu S, Peng H, Mijiti A, Zhang H, Ma H (2017) A chickpea NACtype transcription factor, CarNAC6, confers enhanced dehydration in Aribidopsis. Plant Molecular Biology Reporter 35:83-96 https://doi.org/10.1007/s11105-016-1004-0

Locatelli b, Pavageau c, Pramova E, Di Gregorio M (2015) Integrating climate change mitigation and adaptation in agriculture and forestry: opportunities and trade-offs. WIREs Clim Change 6:585-598 https://doi.org/10.1002/wcc.357

Luo K, Duan H, Zhao D, Zheng X, Deng W, Chen H, Steward CN, McAvory R, Jiang X, Wu Y, He A, Pei Y, Li Y (2007) “GM-gene deletor": fused loxP-FRT recognition sequences dramatically improve the efficiency of $F L P$ or CRF recombinase on transgene excision from pollen and seed of tobacco plants. Plant Biotech. J. 5:263-274. https://doi.org/10.1111/j.1467-7652.2006.00237.x

Lynch AJJ, Barnes RW, Cambecedes J, Vaillancourt RE (1998) Genetic evidence that Lomatia tasmanica (Proteaceae) is an ancient clone. Aust J Bot 46:25-33 https://doi.org/10.1071/bt96120

Lynch AJJ, Balmer J (2004) The ecology, phytosociology and stand structure of an ancient endemic plant Lomatia tasmanica (Proteaceae) approaching extinction. Aust. J. Bot 52:619-627. https://doi.org/10.1071/bt03023

Ma X, Zhu Q, Liu YG (2016) CRISPR/Cas9 platform for genome editing in plants: developments and applications. Molecular Plant 9:961-974 https://doi.org/10.1016/j.molp.2016.04.009

Mahi Y, Franklin J, Seddon N, Solan M, Turner MG, Field CB, Knowlton N (2019) Climate change and ecosystems: threats, opportunities and solutions. Phil Trans R Soc B 375:20190104. https://doi.org/10.1098/rstb.2019.0104

Marchetti C (1977) On geoengineering and $\mathrm{Co}_{2}$ problem. Climate Change 1:59-68 https://doi.org/10.1007/bf00162777

Marum L, Rocheta M, Maroco J, Oliveira MM, Miguel C (2009) Analysis of genetic stability at SSR locus during somatic embryogenesis in maritime pine (Pinus pinaster). Plant Cell Rep 28:673-682 https://doi.org/10.1007/s00299-008-0668-9

Matemilola S, Salami HA (2020) Net zero emission. In: Idowu SO et al. (eds) Encyclopedia of sustainable management. Springer Nature, Switzerland, pp. 1-6 https://doi.org/10.1007/978-3-030-02006-4 512-1

May MR, Provance MC, Sanders AC, Ellstrand NC, Ross-Ibarra J (2009) A Pleistocene clone of Palmer's oak persisting in southern California. PLoSOne 4:e8346. https://doi.org/10.1371/journal.pone. 0008346

McHughen A, Smyth S (2008) US regulatory system for genetically modified [genetically organisms (GMO), rDNA or transgenic] crop cultivars. Plant Biotechnol J 6:2-12. https://doi.org/10.1111/j.1467-7652.2007.00300.x

McKenney DW, Pedlar J, Lawrence K, Moe R, Hutchinson MF (2007) Potential impact of climate change on the distribution of North American trees. Bioscience 57:939-948. https://doi.org/10.1641/b571106

Meason DF, Kennedy SG, Dungey HS (2016) Two New Zealand-based common garden experiments of the range-wide 'Kuser" clonal collection of Sequoia sempervirens reveal pattern of provenance variation in growth and wood properties. New Forests 47:635-651 https://doi.org/10.1007/s11056-016-9535-7

Melchior GH (1985) Züchtung von Aspen und Hybridaspen und ihre Perspetiven für die Praxis. Allg Forst J Ztg 156:112-122

Miller ZD, Peralta PN, Mitchell PH, Kelley SS, Chiang VL, Pearson L, Rottmann WH, Cunningham MW, Peszlen IM (2019) Anatomical, physical, and me- 
chanical properties of transgenic loblolly pine (Pinus taeda $\mathrm{L}$.) modified for increased density. Wood and Fiber Sci 51: 1-10 https://doi.org/10.22382/wfs-2019-018

Mishra N, Tripathi MK, Tiwari S, Tripathi N, Sapre S, Ahuja A, Tiwari S (2021) Cell suspenstion culture and in vitro screening for drought tolerance in soybean using poly-ethylene glycol. Plants 10:517. https://doi.org/10.3390/plants10030517

Mitton JB, Grant MC (1996) Genetic variation and the natural history of quaking aspen. Bioscience 46:25-31. https://doi.org/10.2307/1312652

Mock KE, Rowe CA, Hooten MB, DeWoody J, Hipkin VD (2008) Clonal dynamics in western Norrth American aspen (Populus tremuloides). Mol Ecol 17:4827-4844. https://doi.org/10.1111/j.1365-294x.2008.03963.x

Monleon VJ, Lintz HE (2015) Evidence of tree species range shifts in a complex landscape. PLoSONE 10: e0118069 https://doi.org/10.1371/journal.pone.0118069

Montalbán IA, Garciá-Mendiguren O, Goicoa T, Ugarte MD, Moncaleán P (2014) Can we induce tolerance to stress in Pinus radiata somatic embryos? In: Park YS, Bonga JM (eds) Proceedings of the IUFRO WP 2.09.02, conference on Woody plant production integrating genetic and vegetative technologies. Vitoria-Gasteiz, Spain, pp 22-28

Movahedi A, Zang J, Gao P, Yang Y, Wang L, Yin T, Kadhodaei S, Ebrahimi M, Zhuge Q (2015) Expression of chickpea CarNAC3 gene enhances salinity and drought tolerance in poplars. Plant Cell Tissue and Organ culture 120:141-154 https://doi.org/10.1007/s11240-014-0588-z

Nagmani R, Bonga JM (1985) Embryogenesis in subculture callus of Larix decidua. Can J For Res 15:1088-1091. https://doi.org/10.1139/x85-177

Nave LE, Walters BF, Hofmeister KL, Perry CH, Mishra U, Domke GM, Swanston CW (2019) The role of reforestation in carbon sequestration. New Forests 50:115-137. https://doi.org/10.1007/s11056-018-9655-3

Neale DB, Kremer A (2011) Forest tree genomics: growing resources and applications. Nature Reviews Genetics 12:111-122. https://doi.org/10.1038/nrg2931

Oberg L, Kullman L (2011) Ancient subalpine clonal spruces (Picea abies): sources of postglacial vegetation history in the Swedish Scandes. Arctic 64:183196. https://doi.org/10.14430/arctic4098

O'Gorman PA and Schneider T (2009) The extreme basis for increase in precipitation extremes in simulations of the 21 st-century climate change. Proc Natl Acad Sci USA 106:14773-14777. https://doi.org/10.1073/pnas.0907610106

O'Hara KL, Cox LE, Nikolaeva S, Bauer JJ, Hedges R (2017) Regeneration dynamic of coast redwood, a sprouting conifer species: a review with implications for management and restoration. Forests 8:144 https://doi.org/10.3390/f8050144

Olson DF, Roy DF, Walters GA (1990) Sequoia sempervirens (D. Don) Endl. Redwood. In: Burns RM, Honkala BH (eds) Silvics of North America. Vol 1. Conifers. Agriculture Handbook 654. US Department of Agriculture, Forest Service, Washington DC, pp 541-551

Ostry ME, Ward KT (2003) Field performance of Populus expressing somaclonal variation in resistance to Septoria musiva. Plant Sci 164:1-8 https://doi.org/10.1016/s0168-9452(02)00282-0

Pardos JA, Ahuja MR, Rossello RE (1994) Biotechnology of trees. Investigacion Agraria, Sistemas y recursos Forestales, INIA, Madrid, Spain

Park YS, Bonga JM, Park YS, Moon HK (2010) Proceedings of the IUFRO WP 2.0902, conference on Advances of trees and its application for the future forests and world plantations. Suwon, Republic of Korea

Park YS, Bonga J (2012) Proceedings of the IUFRO WP 2.09.02, conference on "Integrating vegetative propagation, biotechnologies and genetic improvement for tree production and sustainable forest management. Brno, Czech Republic.

Park YS, Bonga JM (2014) Proceedings of the IUFRO WP 2.09.02, conference on Woody plant production integrating genetic and vegetative technologies. Vitoria-Gasteiz, Spain

Park YS, Bonga JM, Moon HK (2016) Vegetative propagation of forest trees. National Institute of Forest Sciences (NIFoS), Korea

Parmesan C (2006) Ecological and evolutionary responses to recent climate change. Annual Review of Ecology, Evolution and Systematics 37:637-669 https://doi.org/10.1146/annurev.ecolsys.37.091305.110100

Parmesan C, Yohe G (2003) A globally coherent fingerprint of climate change impacts across natural systems. Nature 421:37-42 https://doi.org/10.1038/nature01286
Pearson RG, Stanton JC, Shoemaker KT, Aiello-Lammens ME, Ersts PJ, Horning N, Fordham DA, Raxworthy CJ, Ryu HY, McNees J, Akcakaya R (2014) Life history and spatial traits predict extinction risk due to climate change. Nature Climate Change 4:217-221. https://doi.org/10.1038/nclimate2113

Pilate G, Allona L, Boerjan W, Déjardin A, Fladung M, Gallardo F, Häggmann H, Jansson S, Van Acker R, Halpin C (2016) Lessons from 25 years of GM tree field trials in Europe and prospects for the future. In: Vettori C, Gallardo F, Häggman H, Kazana V, Migliaci F, Pilate G, Fladung M (eds) Biosafety of forest transgenic trees. Springer Verlag, Dordrecht, pp 67-100 https://doi.org/10.1007/978-94-017-7531-1_4

Porth I, El-Kassaby YA (2014) Current status of the development of genetically modified (GM) forest trees world-wide: a comparison with the development of other GM plants in agriculture. CAB Reviews 9, 008, pp 1-12 https://doi.org/10.1079/pavsnnr20149008

Prevéy JS, Rixen C, Rüger N, Hoye T, Bjorkman AD, Meys-Smith IH, Elmendorf SC, Ashton IW, Cannome N, Chrisholm CL, Clark K, Cooper RJ, Eleberlin B, Fosaa AM, Henry GHR, Hollister RD, Jónsdóttir IV, Klandreud K, Koop CW, Lévesque E, Mauritz M, Molau U, Natali SM, Oberbauer SF, Panchen ZA, Post E, Rumpf SB, Schmidt NM, Shuur E, Semenchuk PR, Smith JG, Sudig KN, Totland O, Troxler T, Venn S, Wahren C-H, Welker JM, Wipf S (2019) Warming shortens flowering seasons of tundra plant communities. Nature Ecology and Evolution 3:45-52. https://doi.org/10.1038/s41559-018-0745-6

Puchta $\mathrm{H}$ (2017) Applying CRISPR/Cas9 for genome engineering in plants: the best is yet to come. Current Opinion Plant Biol 36:1-8 https://doi.org/10.1016/j.pbi.2016.11.011

Quirk J, McDowell NG, Leake JR, Hudson PJ, Beerling DJ (2013) Increased susceptibility to drought-induced mortality in Sequoia sempervirens (Cupressaceae) trees under Cenozoic atmospheric carbon dioxide starvation. Am J Bot 100:582-591. https://doi.org/10.3732/ajb.1200435

Ramawat KG, Mérillon JM, Ahuja MR (2014) Tree Biotechnology. CRC Press, Boca Raton. https://doi.org/10.1201/b16714

Rehfeldt GE, Jaquish BC, Sáenz-Romero C, Joyce DG, Leites LP, St Clair, JB, López-Upton (2014) Comparative genetic response to climate in the varieties of Pinus ponderosa and Pseudotsuga menziesii: restoration. For Ecol Manage 324:147-157. https://doi.org/10.1016/j.foreco.2014.02.040

Richardson DM, Hellermann JJ, McLachlan JS, Sax DF, Schwartz MW, Gonzalez P, Brennan EJ, Camancho A, Root TL, Sala OE, Schneider SH, Ashe DM, Clark JR, Early R, Etterson JR, Fielder ED, Gill GL, Minteer BA, Polasky S, Safford HD, Thompson AR, Vellend M (2009) Multidimensional evaluation of managed relocation. Proc Natl Acad Sci USA 106:9721-9724 https://doi.org/10.1073/pnas.0902327106

Rocky Mountain Tree-Ring Research (2016) Oldlist database of ancient trees. www.rmtrr.org/oldlist.html

Robock A (2014) Stratospheric aerosol geoengineering. In: Hester RE, Harrison RM (eds) Geoengineering of climate change, Royle Society of Chemistry, London, pp 162-185. https://doi.org/10.1039/9781782621225-00162

Rogelj J, Gerden O, Cowie A, Reisinger A (2021) Three ways to improve net-zero emission targets. Nature 591:365-368

Román-Palacios C, Wiens J (2020) Recent response to climate change reveal the drivers of species extinction and survival. Proc Natl Acad Sci USA 117:42114217. https://doi.org/10.1073/pnas.1913007117

Sangle PM, Satpute SB, Khan FS, Rode NS (2015) Impact of climate change on insects. Trends Bioscience 8:3579-3582

Schmuelling T, Schell J, Spena A (1988) Single gene from Agrobacterium rhizogenes influences plant development. EMBO Journal 7:2621-2629 https://doi.org/10.1002/j.1460-2075.1988.tb03114.x

Schwartz MW, Iverson LR, Prasad AM, Matthews SN, O'Connor RJ (2006) Predicting extinctions as a result of climate change. Ecology 87:1611-1615 https://doi.org/10.1890/0012-9658(2006)87[1611:peaaro]2.0.co;2

Schwartz MW, Hellmann JJ, McLachlan JM, Sax DF, Borewitz JO, Brennan J, Camacho AE, Caballos G, Clark JR, Doremus H, Early R, Etterson JR, Fielder D, Gill JL, Gonzalez P, Green N, Hannah L, Jamieson DE, Javeline D, Minteer BA, Odenbaugh J, Polasky S, Richardson DM, Root, TL, Safford HD, Sala O, Schneider SH, Thompson AR, Williams JW, Vellend M, Vitti P, Zellmer S (2012) Managed relocation: integrating the scientific, regulatory, and ethical challenges. Bioscience 62:732-742. https://doi.org/10.1525/bio.2012.62.8.6

Schulman E (1958) Bristlecone pine, oldest known living thing. National Geographics 113:355-372 
Sederoff, R (2007) Regulatory science in forest biotechnology. Tree Genetics \& Genomes 3: 71-74. https://doi.org/10.1007/s11295-006-0081-x

Seppänen S-K, Syrjälä L, Von Weissenberg K, Teeri TH, Paajanen L, Pappinen A (2004) Antifungal activity of stilbenes in vitro bioassays and in transgenic Populus expressing a gene encoding pinosylvin synthase. Plant Cell Rep 22:584-593. https://doi.org/10.1007/s00299-003-0728-0

Skendvžić S, Zovko M, Živković IP, Lešić V, Lemić D (2021) The impact of climate change on agricultural insect pests. Insects 12:240 doi.org/10.3390/insects12050440. https://doi.org/10.3390/insects12050440

Sillett SC, van Pelt R, Carroll AL, Kramer RD, Ambrose AR, Trask D (2015) How do tree structure and old age affect growth potential of California redwoods? Ecological Monographs 85:181-212. https://doi.org/10.1890/14-1016.1

Smouse PE, Robledo-Arnuncio JJ, González-Martínez SC (2007) Implications of natural propagule flow for containment of genetically modified trees. Tree Genetics \& Genomes 3: 141-152 https://doi.org/10.1007/s11295-006-0075-8

Sommer HE, Brown CL, Kormanik PP (1975) differentiation of plantlets in long leaf pine (Pinus palustris Mill.) tissue cultured in vitro. Bot Gaz 136:196-200 https://doi.org/10.1086/336802

Spena A, Schmuelling T, Koncz G, Schell J (1987) Independent and synergistic activity of rol $A, B$ and $C$ in stimulating abnormal growth in plants. EMBO Journal 6:3891-3899. https://doi.org/10.1002/j.1460-2075.1987.tb02729.X

Staudt A, Leidner AK, Howard J, Brauman KA, Dukes JS, Hansen L, Paukert G, Sabo J, Solórzano LA (2013) The added complications of climate change: understanding and managing biodiversity and ecosystems. Front Ecol Environ 11:494-501. https://doi.org/10.1890/120275

Stebbins GL (1948) The chromosomes and relationship of Metasequoia and Sequoia. Science 108: 95-98. https://doi.org/10.1126/science.108.2796.95

Strauss SH, Rottmann WH, Brunner AM, Sheppard LA (1995) Genetic engineering of reproductive sterility in forest trees. Mol Breed 1:5-26 https://doi.org/10.1007/bf01682086

Strauss SH, Schmitt M, Sedjo R (2009a) Forest scientists views on regulatory obstacles to research and development of transgenic forest biotechnology. J For 107:350357

Strauss SH, Tan H, Boerjan W, Sedjo R (2009b) Strangled at birth? Forest biotechnology and the convention on biological diversity. Nat Biotechnol 27:519-527 https://doi.org/10.1038/nbt0609-519

Sukegawa S, Sika H, Toki S (2021) Plant genome editing ever more precise and wide reaching. The Plant Journal. https://doi.org/10.1111/tpj.15233

Sul IW, Korban SS (2005) Direct shoot organogenesis from needles of three genotypes of Sequoia semperviren. Plant Cell Tissue Org 80:353-358 https://doi.org/10.1007/s11240-004-1365-1

Takolander A, Hickler T, Meller L, Cabeza A (2019) Comparing future shifts in tree species distributions across Europe projected by statistical and dynamic process-based models. Regional Enviromental Change 19:251-266 https://doi.org/10.1007/s10113-018-1403-x

Tang W, Newton RJ (2003) Genetic transformation of conifers and its application in forest biotechnology. Plant Cell Rep 22:1-15 https://doi.org/10.1007/s00299-003-0670-1

Thomas CD, Cameron A, Green RE, Bakkenes M, Beaumont LJ, Collingham YC, Erasmus BFN, de Siqueira MF, Grainger A, Hannah L, Hughes L, Huntley B, van Jaarsveld AS, Midgley GF, Miles L, Ortega-Huerta MA, Peterson AT, Phillips OL, Williams SE (2004) Extinction risk from climate change. Nature 427:145-148. https://doi.org/10.1038/nature02121

Thuiller W, Albert C, Araújo MB, Berry PM, Cabeza M, Guisan A, Hickler T, Midgley GF, Peterson J, Schurr FM, Sykes MT, Zimmermann NE (2008) Predicting global change impacts on plant species distributions: future challenges. Perspectives in Plant Ecol Evol Syst 9:137-152 https://doi.org/10.1016/j.ppees.2007.09.004

Tikkinin M, Varis S, Aronen T (2018) Development of somatic embryo maturation and growing techniques of Norway spruce emblings towards large-scale field testing.Forests 9:325. https://doi.org/10.3390/f9060325

Traenkner C, Lrhmann S, Hoenicka H, Hanke MV, Fladung M, Lenhardt D, Dunemann F, Gau AE, Schlangen K, Malnoy M, Flachowsky H (2010) Over-expression of an $F T$-homologous gene of apple induces early flowering in annual and perennial plants. Planta 232:1309-1324 https://doi.org/10.1007/s00425-010-1254-2
Tremblay L, Levasseur C, Tremblay FM (1999) Frequency of somaclonal variation in plants of black spruce (Picea mariana, Pinaceae) and white spruce ( $P i$ cea glauca, Pinaceae) derived from somatic embryogenesis and identification of some factors involved in genetic instability. Am J Bot 86:1373-1381 https://doi.org/10.2307/2656920

Trenberth KE (2011) Changes in precipitation with climate change. Climate Research 47:123-138. https://doi.org/10.3354/cr00953

Trontin JF, Harvengt L, Garin E, Lopez-Vernaza M, Arancio L, Hoebeke J, Canlet F, Pâques M (2002) Towards genetic engineering of maritime pine (Pinus pinaster Ait). Am For Sci 59:687-697. https://doi.org/10.1051/forest:2002057

Trontin JF, Walter C, Klimaszewska K, Park, YS, Lelu-Walter MA (2007) Recent progress in genetic transformation of four Pinus spp. Transgenic Plant Journal 1:314-329

Trontin JF, Teyssier C, Morel A, Harvengt L, Lelu-Walter (2016) Prospects of new variety development through somatic embryogenesis in maritime pine. In: Park YS, Bonga JM, Moon HK (eds) Vegetative propagation offorest trees. National Instituteb of Forest Sciences, Suwon, Korea, pp 572-606

Tsai CJ, Xue LJ (2015) CRISPRing in the woods. GM Crops \& Food 6:206-215 https://doi.org/10.1080/21645698.2015.1091553

Tycko J, Myer VE, Dsu PD (2016) Methods for optimizing CRISPR-Cas9 editing specificity. Mol Cell 63:355-370. https://doi.org/10.1016/j.molcel.2016.07.004

Uddenberg D, Abrahamsson M, von Arnold S (2016) Overexpression of PaHA$P 3 A$ stimulates differentiation of ectopic embryos from maturing somatic embryos of Norway spruce. Tree Genetcs \& Genomes 12:18 https://doi.org/10.1007/s11295-016-0974-2

Urban MC (2015) Accelerating extinction risk from climate change. Science 348:571-573. https://doi.org/10.1126/science.aaa4984

USDA (2019) Revision to USDA-APHIS 7 CFR part 340 regulations governing the importation, interstate movement, and environmental release of certain genetically engineered organisms. Draft programmatic environmental impact statement May, 2019. Washington, DC, pp. 1-449

USDA (2020) Movement of certain genetically engineered organisms. Federal Register 85, No. 96, May 18, 2020/ (Rules and Regulations)

Verma D, Daniell H (2007) Chloroplast vector systems for biotechnology applications. Plant Physiol. 145: 1129-1143. https://doi.org/10.1104/pp.107.106690

Vettori C, Gallardo F, Häggman H, Kazana V, Migliaci F, Pilate G, Fladung M (2016) Biosafety of forest transgenic trees. Springer Verlag, Dordrecht https://doi.org/10.1007/978-94-017-7531-1

Wagner A, Phillips L, Narayan RD, Moody JM, Geddes B (2005) Gene silencing studies in the gymnosperm Pinus radiata. Plant Cell Rep 24: 95-102 https://doi.org/10.1007/s00299-004-0911-y

Wani SH, Sah SK, Sanghera G, Hussain W (2016) Genetic engineering for cold stress tolerance in crop plants. Advances in Genome Science 4:173-201 https://doi.org/10.2174/9781681081731116040010

Wann SR, Einspahr DW (1986) Reliable plantlet formation from seedling explants of Populus tremuloides (Michx.). Silvae Genet 35:19-24

Wear DN, Abt RC, Dixon E, Singh N (2014) Projecting potential adaptation of genetically engineered freeze-tolerant Eucalyptus in the United States. Forest Sci 61. https://doi.org/10.5849/forsci.14-089

White TL, Adams WT, Neale DB (2007) Forest genetics. CABI International Publishing, Cambridge, MA. https://doi.org/10.1079/9781845932855.0000

Williamson P, Wallace DWR, Law CS, Boyd PW, Collos Y, Croot P, Denman K, Riebesell U, Takeda S, Vivian C (2012) Ocean fertilization for geoengineering: a review of effectiveness, environmental impacts and emerging governance. Process Safety Environ Prot 90:475-488 https://doi.org/10.1016/j.psep.2012.10.007

Winton LL (1968) Plantlets from aspen tissue culture. Science 160:1234-1235 https://doi.org/10.1126/science.160.3833.1234

Wisniewski M, Nassuth A, Teulieres C, Marque C, Rowland J, Cao PB, Brown A (2014) Genomics of cold hardiness in woody plants. Crit Rev Plant Sci 33:92124. https://doi.org/10.1080/07352689.2014.870408

Zhang Z, Moore JC, Huisingh, Zhao Y (2015) Review of geoengineering approaches to mitigating climate change. J Cleaner Production 103:898-907 https://doi.org/10.1016/j.jclepro.2014.09.076

Zhou X, Jacobs TB, Xue LJ (2015) Exploiting SNPs for biallelic CRISPR mutations in the outcrossing woody perennial Populus reveals 4-coumarate: $\mathrm{CoA}$ ligase specificity and redundancy. New Phytol 208:298-301 https://doi.org/10.1111/nph.13470 
Zobel B, Talbert J (1984) Applied forest tree improvement. John Wley and Sons, New York 